\title{
Political Risk, Economic Risk and Financial Risk
}

\author{
Claude B. Erb \\ First Chicago Investment Management Co., Chicago, IL 60670 \\ Campbell R. Harvey \\ Duke University, Durham, NC 27708 \\ National Bureau of Economic Research, Cambridge, MA 02138 \\ Tadas E. Viskanta \\ First Chicago Investment Management Co., Chicago, IL 60670
}

1 Erb-Harvey-Viskanta--Political Risk, Economic Risk and Financial Risk: May 6, 1996. 


\title{
Political Risk, Economic Risk and Financial Risk
}

\begin{abstract}
How important is an understanding of country risk for investors? Given the increasingly global nature of investment portfolios, we believe it is very important. Our paper measures the economic content of five different measures of country risk: The International Country Risk Guide's political, financial, economic and composite risk indices and Institutional Investor's country credit ratings. We explore whether any of these measures contain information about future expected stock returns. Next, we conduct time-series-crosssectional analysis linking these risk measures to future expected returns. Finally, we analyze the linkages between fundamental attributes within each economy, such as bookto-price ratios, and the risk measures. Our results suggest that the country risk measures are correlated future equity returns. In addition, country risk measures are highly correlated with equity valuation measures. This provides some insight into the reasonwhy valueoriented strategies generate high average returns.
\end{abstract}

2 Erb-Harvey-Viskanta--Political Risk, Economic Risk and Financial Risk: May 6, 1996. 


\title{
Political Risk, Economic Risk and Financial Risk
}

\begin{abstract}
SHORT ABSTRACT
We assess the economic importance of political, economic and financial measures of country risk. While the country risk measures contain unique information, they are highly correlated with equity valuation measures, such as price-to-book ratios. This helps explain why value-oriented strategies generate high average returns.
\end{abstract}

3 Erb-Harvey-Viskanta--Political Risk, Economic Risk and Financial Risk: May 6, 1996. 


\section{Introduction}

What is country risk and how should it impact global investment strategies? We explore the information in five different measures of country risk. The first four measures are from Political Risk Services’ International Country Risk Guide (ICRG). These measures include political risk, economic risk and financial risk. The ICRG also reports a measure of composite risk which is a simple function of the three base indices. The final measure we examine is Institutional Investor's country credit ratings. We define the information content in a number of different ways.

We initially explore whether the risk indices contain information about future expected returns. ${ }^{1}$ This analysis is conducted in two ways. First, we form a portfolio of countries which experience a decrease in the risk rating (become more risky) and a portfolio of countries which experience an increase in the risk rating (become less risky). We form the portfolio after the risk information is available and rebalance the portfolio every six months. We find that there is, indeed, information about expected equity returns in these measures. We supplement this analysis with a time-series cross-sectional regressions which measure the amount of information contained in each metric. We find that the financial risk measure contains the most information about future expected returns and political risk contains the least.

The next part of our analysis investigates the link between these country risk measures and some more standard measures of risk. We investigate whether there is a correlation

\footnotetext{
${ }^{1}$ To ensure the widest possible dissemination of our methodology, we have established a country risk homepage:

http://www.duke.edu/ charvey/Country_risk/couindex.htm

This site includes information on 135 different countries which could not be included in this manuscript. For example, the site contains equity return histograms for 48 countries, timeseries graphs of the five risk measures for 117 countries, summary statistics, as well as the most recent version of this paper and the associated tables and exhibits.
}

4 Erb-Harvey-Viskanta--Political Risk, Economic Risk and Financial Risk: May 6, 1996. 
between a country's beta against the $\mathrm{MSCl}$ world index. While this is a standard risk measure for integrated capital markets, many have found the world beta model inadequate to characterize risk in emerging markets. As an alternative, we also investigate the relation between the country risk measure and equity volatility.

The final part of our paper explores the interface between country risk analysis and investment strategies based on country fundamental information, such as book-to-price ratios. We find that the risk indices are highly correlated with the fundamental attributes. This provides some economic insight as to why value-oriented strategies earn higher returns -- they reflect higher risk exposure.

There has been relatively little research in finance that focusses on the economic content of various country ratings. Political risk measures have been studied in Harlow (1993) and Diamonte, Liew and Stevens (1996). Erb, Harvey and Viskanta (1995) examine the information in credit risk measures. Our current study investigates a broad cross-section of different risk measures.

\section{Measuring Country Risk}

There are many services that measure country risk: ${ }^{2}$

- $\quad$ Bank of America World Information Services

- $\quad$ Business Environment Risk Intelligence (BERI) S.A.

- Control Risks Information Services (CRIS)

- $\quad$ Economist Intelligence Unit (EIU)

- $\quad$ Euromoney

- Institutional Investor

\footnotetext{
${ }^{2} \mathrm{An}$ appendix which is available on request provides information and comparisons of these on these providers.

5 Erb-Harvey-Viskanta--Political Risk, Economic Risk and Financial Risk: May 6, 1996.
} 
- $\quad$ Standard and Poor's Rating Group

- $\quad$ Political Risk Services: International Country Risk Guide (ICRG)

- Political Risk Services: Coplin-O’Leary Rating System

- Moody’s Investor Services

Each of the index or rating providers must amalgamate a range of qualitative and quantitative information into a single index or rating. In this section, we review in detail the methodologies used by two of the foremost providers of risk ratings: Institutional Investor and International Country Risk Guide (ICRG).

\subsection{Institutional Investor}

Institutional Investor credit ratings are based on a survey of leading international bankers who are asked to rate each country on a scale from zero to 100 (where 100 represents maximum creditworthiness). Institutional Investor averages these ratings, providing greater weights to respondents with greater worldwide exposure and more sophisticated country analysis systems.

Whenever a survey or expert panel is used to subjectively rate creditworthiness, it is hard to exactly define the parameters taken into account. At any given point in time an expert's recommendation will be based upon factors the expert feels are relevant.

In order to identify the factors that its survey participants have taken into consideration in the past, Institutional Investor asks them to rank the factors that they take into account in preparing country ratings. The results of this survey are listed in Table 1 . Note that the bankers rank factors differently for different groups of countries and that rankings have changed over time within country groups. The ranking of factors affecting OECD country ratings appear to have been the most turbulent over the fifteen-year period.

6 Erb-Harvey-Viskanta--Political Risk, Economic Risk and Financial Risk: May 6, 1996. 


\subsection{International Country Risk Guide}

ICRG compiles monthly data on a variety of political, financial and economic risk factors to calculate risk indices in each of these categories as well as a composite risk index. Five financial, thirteen political and six economic factors are used. Each factor is assigned a numerical rating within a specified range. The specified allowable range for each factor reflects the weight attributed to that factor. A higher score indicates lesser risk.

Political risk assessment scores are based on subjective staff analysis of available information. Economic risk assessment scores are based upon objective analysis of quantitative data and financial risk assessment scores are based upon analysis of a mix of quantitative and qualitative information.

Calculation of the three individual indices is simply a matter of summing up the point scores for each factor within each risk category. The composite rating is a linear combination of the three individual indices' point scores. Note that the political risk measure (100 points) is given twice the weight of financial and economic risk (50 points each). ICRG, as well as many of the other providers, think of country risk as being composed of two primary components: ability to pay and willingness to pay. Political risk is associated with a willingness to pay while financial and economic risk are associated with an ability to pay.

The specific formulas for these calculations are as follows:

$P R=\Sigma P R_{\mathrm{i}}, \quad E R=\Sigma E R_{\mathrm{i}}, \quad F R=\Sigma F R_{\mathrm{i}} \quad$ and $C R R=0.5^{\star}(P R+E R+F R)$.

where $\mathrm{PR}$ is political risk, ER is economic risk, FR is financial risk and CRR is the composite risk rating. The specific factors taken into account for each risk index are detailed in Table 2.

ICRG also groups country composite scores into ordinal risk categories to facilitate quick

7 Erb-Harvey-Viskanta--Political Risk, Economic Risk and Financial Risk: May 6, 1996. 
interpretation and comparison of country scores. This categorization scheme is presented in Table 3.

\subsection{Index and Rating Provider Comparison}

A wide range of groups provide country risk or country credit ratings. Although the factors taken into account by each group and the audience they seek to inform vary, there are significant similarities across the providers of these measures.

Most of the providers transform widely use quantitative economic indicators in roughly the same manner. The important differences are found in the degree of and specific factors included in the qualitative component of the risk index measures.

Table 4 provides a comparison of S\&P and Moody's Ratings with both the II and ICRG ratings. The table reports the ratings in October 1995. There is a close correspondence between the S\&P and Moody's ratings and the II credit risk measure with a rank order correlation of $95 \%$. There is also a strong correlation between these ratings and the ICRG financial rating (rank order correlation of $90 \%$ ). The correlations are weaker for the other measures. For example, the rank order correlation of the Moody's rating and the ICRG economic rating is only $68 \%$.

\section{Summary Data Analysis}

\subsection{Variation in risk measures}

8 Erb-Harvey-Viskanta--Political Risk, Economic Risk and Financial Risk: May 6, 1996. 
Our analysis focuses on 117 countries. For these countries, we have all five risk indices. ${ }^{3}$ We segment the countries into five groups: All countries, countries with equity markets, developed countries with equity markets, emerging countries with equity markets and countries without equity markets.

Figure 1 presents time-series graphs of the equally weighted risk indices for three groups over the January 1984-July 1995 period: Developed (with equity markets), emerging (with equity markets) and all other countries.

The equally-weighted measures for the developed countries (Panel A) exhibit remarkably little variation through time. The ICRG financial and economic measure remain about the same throughout the sample, as does the II country credit rating. There is a small decline the ICRG political rating.

The analysis for the emerging countries and all other countries (Panels $B$ and $C$ ) is similar. Many of the other countries have similar economic characteristics to the emerging country sample. Generally, all of the risk rating measures increase over the sample. This is particularly evident over the 1988 to 1993 period.

The cross-sectional behavior of the risk measures is explored in Figure 2. For the countries with equity returns and all countries (with and without equity markets), we graph the January 1984 risk level against the change in the risk level up to July 1995. The panels analyze all five measures: II credit risk and the ICRG political, economic, financial and composite risk. The cross-sectional mean reversion in the political risk measure that Diamonte, Liew and Stevens (1996) document also occurs in the other risk measures. Those countries that began with a very low risk rating tend to improve. Those countries with a high rating have tended to deteriorate.

\footnotetext{
${ }^{3}$ Time-series graphs of the risk indices for each country are available through the country risk web site, http://www.duke.edu/ charvey/Country_risk/couindex.htm. 9 Erb-Harvey-Viskanta--Political Risk, Economic Risk and Financial Risk: May 6, 1996.
} 
This mean reversion is particularly evident for the financial and composite risk measures for countries with equity markets. There is also evidence that the political and economic risk exhibit the same type of behavior. The weakest evidence of cross-sectional mean reversion is found for the credit risk. There are a number of countries which show sharp improvement in the risk ratings. For example, Argentina begins with a ICRG composite rating of 40.0 and rises to 71.5 by July 1995 . Similar improvements are evident for many of the other Latin American countries. In contrast, some developed markets have shown deterioration, for example, Switzerland dropped from an ICRG composite rating of 95.0 to 88.5 in July 1995. Similar declines were found for Japan, the U.K. and the U.S.

The first panel of Table 7 details the correlation of the various risk measures. Since the credit rating is only available on a semi-annual basis the correlations are presented based on semi-annual observations. The correlation measure is equally weighted across the different countries. The upper triangle of the matrix reports the correlation based on changes in rating and the lower triangle reports the correlation of the levels.

The correlations are not as high as one might expect. Obviously, the correlation between the composite and the political rating is the highest because, by definition, the political rating is $50 \%$ of the composite. However, the highest cross-correlation of the levels of the three ICRG components is 35\%. Interestingly, the correlation between the ICRG financial measure and the II credit rating is only $26 \%$.

The second panel of Table 5 documents the degree of predictability in the risk measures. The levels of the measures are very persistent. We report the average autocorrelations of the changes in the risk measures. The change in the II credit rating is the most predictable. The average first order autocorrelation is $24 \%$ (20\% in developed markets and $26 \%$ in emerging markets). The least predictable measure is the change in the political risk rating. The average autocorrelation is -0.01 (0.03 in developed markets and -0.04 in emerging markets). 
The final part of Table 5 provides a correlation analysis of the ratings with mean returns, volatility and beta against the Morgan Stanley Capital International world market portfolio. The equity returns are from $\mathrm{MSCl}$ and the International Finance Corporation (IFC). First examine the beta. The correlation of each of the risk measures and beta is positive (43\% for beta and the ICRG composite). This is exactly the opposite of what one would expect. The evidence suggests that the highest rated countries (lowest financial, economic and credit risk) have the highest betas. This is evident in panel A of Figure 3 which graphs the betas against the average risk measures. This positive relation is largely due to the fact that the emerging markets have very low betas with respect to the world market portfolio [see Harvey (1995)].

Also notable in this panel is the sharp negative correlation between volatility and the risk measures (see panel B of Figure 3). This closely squares with intuition. The lowest (highest) rated countries have the highest (lowest) equity return volatility. This volatility is robust across all risk measures except for political risk. In emerging markets, there is a positive relation between the political risk and the volatility.

We also investigate whether the ICRG ratings, given that they are made on a more timely basis, contain advance information regarding the II credit rating. These results are contained in Table 6. We find that the February-August and August-next February ICRG rating change predicts the March-September and September-next March II CCR. The regression results show that the ICRG ratings lead the II CCR. Each of the ICRG components enters regressions predicting next period's CCR change with coefficients more than four standard errors from zero. The t-ratio on the ICRG composite measure is 7.6. All coefficients are positive. We also assessed the impact of the change in the II credit rating on the next month's change in the ICRG rating. There is little information here. Only one of the regressions, the financial risk, has a coefficient that is significantly different from zero. However, the coefficients are all negative which makes little sense (increased CCR predicts lower ICRG ratings). We conclude that the ICRG contains information that predicts CCR but the reverse is not true.

11 Erb-Harvey-Viskanta--Political Risk, Economic Risk and Financial Risk: May 6, 1996. 


\subsection{An initial portfolio strategy}

The final panel of Table 5 suggests that there is a relation between average returns and average ratings. One way to analyze this relation is to form a portfolios based on ratings changes. One version of this approach is analyzed in Diamonte, Liew and Stevens (1996). They form two portfolios: upgrade and downgrade based on the ICRG political risk measure. Importantly, their approach is ex post - rather than ex ante. That is, their portfolios are only investable if you knew in advance what next month's rating would be.

An alternative approach is an event strategy which is pursued in Harlow (1993). He examines the cummulative returns of countries up to six months after political rating increases and decreases. This strategy is investable given that countries are purchased or sold after the rating changes.

Our strategy will be to form two portfolios: upgrade and downgrades. The portfolios are rebalanced every six months. If the rating does not change, we keep the country in its respective portfolio. This reduces transactions costs and increases the number of countries in the portfolios.

The first panel of Table 7 complements the Diamonte, Liew and Stevens (1996) results. The upgrade portfolios have higher average returns than the downgrade portfolios. This is true not just for political risk, but also for the other risk measures as well. Indeed, of the four ICRG risk measures, political risk is never the most important measure. In the all country group and the emerging markets, the composite risk measure is more important in the sense that it implies a more profit. In the developed countries, the financial risk measure has the most ability to discriminate between high and low return portfolios.

The second panel of Table 7 presents the results from an investable strategy. Portfolios are based on a previous rating change and held for six months. Each country is equally 
weighted in the portfolios. The results suggest that the composite risk measure has considerable power to identify high and low return portfolios. On a risk adjusted basis, the hedge strategy (buy upgrades and sell downgrades) based on composite risk has an (annualized) alpha of $1140 \mathrm{bp}$ per year when all countries are examined. Interestingly, the political risk measure has an alpha of -160bp per year. The portfolios formed on economic risk have an alpha of $750 \mathrm{bp}$. The portfolios based on financial and credit risk fare worse than the political risk measure.

Perhaps the most interesting aspect of the analysis is that this is not just an emerging markets phenomena. If the portfolio strategy is executed on developed countries, the alpha for the composite risk is $840 \mathrm{bp}$. For the economic risk, the alpha is $540 \mathrm{bp}$. Similar to the overall sample, the financial, political and credit measures fare poorly.

When the emerging markets are examined, the alpha on the composite risk measure is $860 \mathrm{bp}$. For the economic risk, the alpha is $880 \mathrm{bp}$. Consistent with the developed market analysis, financial, political, and credit risk are unable to distinguish between high and low returns in a portfolio strategy.

The performance of these strategies is robust to different country weighting schemes. As an alternative to the equal weighting of countries, we implemented a capitalization weighting strategy. Similar results were found. For example, the risk adjusted return of the composite risk upgrade-downgrade portfolio is $1170 \mathrm{bp}$ per year for the capitalization weighting scheme compared to $1140 \mathrm{bp}$ for the equal weighting [these results are available on request]. Within the country groupings, capitalization weighting makes the economic risk measure more important in developed markets. Capitalization weights make the political risk measure more important in emerging markets.

Finally, some caution should be exercised in interpreting our results because transactions costs have not been taken into account. We have taken two steps to minimize the transactions costs. Turnover is minimized by keeping the zero rating change countries in 
their current portfolio. Second, we only rebalance twice a year. In addition, the our portfolio strategy is sucessful on developed as well as emerging markets. In many of the developed markets, trading costs can be minimized by using index futures.

\section{Cross-sectional analysis of risk}

\subsection{Time-series cross-sectional analysis of risk attributes}

The analysis in Table 7 suggests that portfolio groupings by certain attributes produce positive risk adjusted profits on an ex ante basis (panel B). This simple analysis was based on two portfolios: increased risk rating and decreased risk rating. Much information is potentially lost with such a coarse aggregation. More information can be obtained by trying to predict both the cross-section and the time-series of expected returns based on the risk attributes.

Table 8 presents attribute regressions of form:

$$
R_{t}=c_{0}+c_{1} A_{t-1}+\varepsilon_{t}
$$

where $R$ represents a vector of six-month returns from (earliest) July 1984- June 1995 for all of the countries in our sample (some markets' returns begin later). A represents the risk attribute which is lagged and matched to the country. With our full sample of all countries, there are 884 observations. When developed countries are examined, there are 441 observations. There are 443 observations in the emerging equity market sample.

The first line of Table 8 reports coefficients and t-statistics for five separate regressions of the returns on the attributes. The R-square from this regression and the R-square from a similar regression with indicator variables for each country is also reported (fixed effect regression or FER2). Regressions are estimated on the lagged level of the attribute as well as lagged changes in the attribute. The number of countries in each cross-sectional 
regression grows from 28 in March 1984 to 48 in March 1995.

Panel A reports the regressions using the lagged level of the attribute as an explanatory variable for the cross-section of expected returns. With the full sample of 48 countries, each of the five risk attributes has a coefficient significantly different from zero when the attributes are examined separately. In each case, the coefficient is negative implying that lower rating (higher risk) is associated with higher expected returns. In this analysis, the financial risk variable is most important and the composite is second most important. When a multivariate regression is estimated on four attributes, only the financial risk variable enters the regression with a significant coefficient.

When the regressions are estimated separately on developed and emerging countries, it is clear that the developed countries sample is driving the explanatory power of the entire sample. The ICRG financial risk variable enters the developed country regression with a tratio close to four in the univariate regression. In both the univariate and multivariate regressions, both the ICRG financial and economic risk variables enter the regression while the political risk and II credit risk do not. In the emerging countries sample, no attribute enters the regression with a significant coefficient. However, the closest variables are the ICRG financial and economic risk variables.

The second panel of Table 8 examines regressions of country returns on the lagged change in the attributes. This panel is closer to the trading strategy results in Table 7 where portfolios were constructed of countries whose rating had changed. While the change regressions have less explanatory power than the lagged levels, there are many similarities between panel A and panel B. In particular, in the developed country sample, the ICRG financial variable is by far the most important with t-ratios close to two. In contrast to Panel A, the political risk variable is important - but only for the emerging market sample.

Overall, the regression evidence complements the evidence from the portfolio strategies. However, the regression results do not seem as dramatic as profits from the portfolio 
strategies. This could be driven by the fact that the value of the change variable is often zero.

\subsection{The relation between the risk attributes and fundamental variables}

Ferson and Harvey (1995) provide evidence fundamental attributes, such as book-to-price, earnings-price, dividend-to-price, and price-to-cash ratios, are linked to the risk exposure of national markets. They propose an asset pricing framework where the fundamental attributes are linked to dynamic country risk (beta) functions. We now explore whether our set of risk variables are also linked to fundamental attributes.

We focus on a set of three attributes that are available for both the developed and emerging markets: book-to-price, earnings-price and dividend-to-price ratios. Table 9 provides cross-sectional regressions that attempt to explain the cross-section of the valuation attributes using our country risk measures. Similar to Table 8 , both univariate regressions and multivariate regression are presented for three different samples. We will focus our discussion on the multivariate regressions. The number of countries in the crosssectional regression varies from 18 in March 1984 to 47 in March 1995.

There are a number of interesting results in Table 9. First, the risk measures have some ability to explain all three valuation ratios. However, the risk measures do the best in explaining the cross-sectional variation in the book-to-price ratios. In the full sample, over $25 \%$ of the variation can be explained using all four risk measures. Of all the component risk measures, the ICRG economic risk rating is the most important accounting for $18 \%$ of the variation in the full sample of countries. The economic risk measure enters with a negative coefficient. This suggests that higher rating (lower risk) is associated with lower book-to-price ratios.

When the data are segmented by developed and emerging countries, the results are similar to the pooled regression. For developed countries, $18 \%$ of the cross-sectional variance of 
the book-to-price ratios can be explained of which the economic risk variable contributes $10 \%$. For the emerging equity markets, $29 \%$ of the variation can be explained in the multivariate model and the economic risk variable contributes $24 \%$.

The risk variable also shows some ability to explain the cross-section of dividend yields. However, with the dividend yield, the results are different across the developed and emerging markets. For the developed markets, a total of $16 \%$ of the cross-sectional variation can be explained. The ICRG economic risk measure contributes $13 \%$ and the financial risk variable contributes $5 \%$ (the contributions need not sum to the total because of correlation between the risk measures). In emerging markets, a similar amount of explanatory power is found, $17 \%$. However, in this case, almost all of the explanatory power is coming from the financial risk which is contributing $16 \%$. In both the developed and emerging market regressions, the two risk variables enter with negative coefficients suggesting that higher rating (lower risk) is associated with lower dividend yields.

The incremental contribution of the risk ratings relative to the book-to-price valuation measure is presented in Table 10. Univariate regressions are estimated in the form

$$
R_{t}=c_{0}+c_{1} A_{t-1}+c_{2} B / P_{t-1}+\varepsilon_{t}
$$

Table 10 reports the coefficients and t-ratios on the risk attribute. The results indicate that there is little or no incremental information in the II credit rating or the ICRG political risk measure. The ICRG financial risk measure is the most important variable followed by the ICRG economic risk. While both the economic and financial risk measures add important incremental explanatory power to the developed country regressions, they have no ability to add to the emerging equity market regressions. For the emerging markets, the book-toprice valuation attribute fully characterizes the information in the risk ratings. 


\subsection{Trading strategies based on risk attributes}

There are two disadvantages of the time-series cross-sectional methodology. First, in stacking the time-series of returns together, important information regarding the crosssectional correlation of the returns is eliminated. This could cause the standard errors to be understated. Second, the time-series cross-sectional methodology imposes the same slope coefficient for all time-periods. It is possible that the slope coefficient could change through time. Ferson and Harvey $(1991,1993)$ find that the variation in the slope coefficients is to some degree predictable.

Panel A of Table 11 reports the results of estimating a cross-sectional regression at each six month interval. The slope coefficients are averaged and the standard error of the average is also presented. The results are largely consistent with those reported in Table 8 for the univariate regressions. For each of the risk measures, the average slope coefficient is negative. In all cases, the slope coefficient is greater than 1.5 standard errors below zero.

Although not reported, we investigated the pattern of estimated cross-sectional slope coefficients through time along with the time-series of R-squares. In all cases, the explanatory power of the risk variables increases through time.

Panel B of Table 11 assesses the incremental contribution of the risk attributes when book value-to-price is included in the cross-sectional regression. While the coefficients are negative for each of the risk attributes, only II credit risk and the ICRG composite and political ratings have coefficients which are more than one standard error below zero.

Panel C of Table 11 implements the Ferson and Harvey (1995) attribute adjustment methodology. Ferson and Harvey make the beta risk (with respect to the $\mathrm{MSCl}$ world portfolio) a function of the attribute. We estimate a time-series regression for each country:

$$
R_{i t}=b_{i 0}+b_{i 1} R_{w, t}+b_{i 2}\left[R_{w, t} \times A_{i, t-1}\right]+\varepsilon_{t}
$$


With the results of this regression, an adjusted attribute is formed:

$$
A_{i, t-1}^{*}=b_{i 1}+b_{i 2} A_{i, t-1}
$$

Panel $\mathrm{C}$ reports regressions of the cross-section of returns on the cross-section of adjusted attributes. Here the coefficient is positive suggesting a positive relation between beta risk and expected returns. While the many of the coefficients are not significantly different from zero at conventional levels, the explanatory power of the regressions uniformly improve over the panel A regressions which consider only the raw attribute. ${ }^{4}$

The final panel in Table 11 considers both the adjusted and unadjusted attribute. Note that there is no problem with collinearity here because the adjustment factors are country specific. Consistent with the results in Panel $\mathrm{C}$, the beta risk factor enters each regression with a positive coefficient. Each of the II and ICRG risk measures enters with a negative coefficient. Notable in this table is the large jump in explanatory power. The average crosssectional R-square for the II credit risk measure is now $26 \%$ (regressing on credit risk alone produces on a $8 \% \mathrm{R}$-square). Both the economic and financial risk measures show similar explanatory power.

\section{Conclusions}

The goal of this research is to explore the economic content of five country risk measures: Institutional Investor's country credit rating and the International Country Risk Guide's political, financial, economic and composite risk ratings. Our analysis suggests that there is

\footnotetext{
${ }^{4}$ For example, the explanatory power of the book-to-market variable doubles after the Ferson-Harvey (1995) attribute adjustment is implemented. This appears to provide considerable support for the Ferson-Harvey method.

19 Erb-Harvey-Viskanta--Political Risk, Economic Risk and Financial Risk: May 6, 1996.
} 
considerable information contained in the ICRG composite, financial and economic ratings, in particular. For example, when we form portfolios based on changes in the risk ratings, we find risk-adjusted abnormal returns in the range of $1000 \mathrm{bp}$ per year. Our exercise shows that trading on the political risk measure alone has no ability to produce abnormal returns.

The cross-sectional regressions confirm the results of the portfolio analysis. We find evidence that some of the ICRG risk measures, in particular, economic and financial risk, can predict the cross-section of expected returns. This is most strongly evidenced in the developed markets in our sample. We also find that the change in the political rating has some marginal explanatory power in emerging equity markets - but not in developed markets.

We find that the country risk ratings are correlated with fundamental valuation attributes. For example, $25 \%$ of the cross-sectional variation in book-to-price can be explained by the risk ratings. This explanatory power is largely driven by the ICRG economic risk which alone can explain $18 \%$ of the cross-sectional variation. These results shed light on the information that determines the fundamental valuation measures. We provide insights on why global value-oriented strategies work.

Our final contribution is to bridge attribute-oriented investment strategies with asset pricing. Ferson and Harvey (1995) argue that popular valuation attributes should enter each country's dynamic risk function. We follow their suggestion and find a relation between dynamic risk with respect to a world benchmark and expected returns. In addition, similar to Ferson and Harvey's results, we find that the attributes are still important for the alpha. That is, even after allowing for the attributes to influence the beta risk, they still have marginal cross-sectional explanatory power when included in the prediction exercise.

\section{Acknowledgements}

We appreciate the help of Chris Rath at Political Risk Services in supplying us with the 
data. Rob Feldman provided valuable research assistance. John Liew and Ross Stevens provided valuable comments on an early draft.

\section{References}

Bekaert, Geert, 1995, Market integration and investment barriers in emerging equity markets, World Bank Economic Review 9, 75--107.

Bekaert, Geert, and Campbell R. Harvey, 1995a, Emerging equity market volatility, Working paper, Duke University and Stanford University.

Bekaert, Geert, and Campbell R. Harvey, 1995b, The cost of capital in emerging markets, Working paper, Duke University and Stanford University.

Bekaert, Geert, and Campbell R. Harvey, 1995c, Emerging capital markets and economic development, Working paper, Duke University and Stanford University.

Black, Fischer, 1972, Capital market equilibrium with restricted borrowing, Journal of Business 45, 444-455.

Diamonte, Robin, John M. Liew and Ross L. Stevens, 1996, Political risk in emerging and developed markets, Financial Analysts Journal, forthcoming.

Erb, Claude B., Campbell R. Harvey and Tadas E. Viskanta, 1994, National risk in global fixed income allocation, Journal of Fixed Income September, 17-26.

Erb, Claude B., Campbell R. Harvey and Tadas E. Viskanta, 1995, Country risk and global equity selection, Journal of Portfolio Management 9, Winter, 74-83.

Erb, Claude B., Campbell R. Harvey and Tadas E. Viskanta, 1996, Expected returns and volatility in 135 countries, Journal of Portfolio Management Spring, 46-58.

Errunza, Vihang R., and Etienne Losq, 1985, International asset pricing under mild segmentation: Theory and test, Journal of Finance 40, 105--124.

Fama, Eugene F. and James D. MacBeth, 1973, Risk, return and equilibrium: Empirical tests, Journal of Political Economy 81, 607-636.

Ferson, Wayne E., and Campbell R. Harvey, 1991, The variation of economic risk premiums, Journal of Political Economy 99, 285-315.

21 Erb-Harvey-Viskanta--Political Risk, Economic Risk and Financial Risk: May 6, 1996. 
Ferson, Wayne E., and Campbell R. Harvey, 1993, The risk and predictability of international equity returns, Review of Financial Studies 6, 527--566.

Ferson, Wayne E., and Campbell R. Harvey, 1994, An exploratory investigation of the fundamental determinants of national equity market returns, in Jeffrey Frankel, ed.: The Internationalization of Equity Markets, (University of Chicago Press, Chicago, IL), 59--138.

Ferson, Wayne E., and Campbell R. Harvey, 1995, Country risk in asset pricing, Working paper, Duke University.

Gibbons, Michael R., 1982, Multivariate tests of financial models: A new approach, Journal of Financial Economics 10, 3-27.

Harlow, W. Van, 1993, Political Risk and Asset Markets, Fidelity Investments Monograph, Boston: MA.

Harvey, Campbell R., 1991, The world price of covariance risk, Journal of Finance 46, 111--157.

Harvey, Campbell R., 1993, Portfolio enhancement with emerging markets and conditioning information, in Stijn Claessens, and Sudarshan Gooptu, eds.: Portfolio investment in developing countries, (World Bank, Washington), 110--144.

Harvey, Campbell R., 1995, Predictable risk and returns in emerging markets, Review of Financial Studies 8, 773-816.

Harvey, Campbell R., Bruno H. Solnik, and Guofu Zhou, 1994, What determines expected international asset returns?, Working paper, Duke University, Durham, NC.

Harvey, Campbell R. and Guofu Zhou, 1993, International asset pricing with alternative distributional assumptions, Journal of Empirical Finance 1, 107-131.

Liew, John M., 1995, Stock returns, inflation, and the volatility of growth in the money supply: Evidence from emerging markets, Working paper, University of Chicago, Chicago, IL.

Lintner, John, 1965, The valuation of risk assets and the selection of risky investments in stock portfolios and capital budgets, Review of Economics and Statistics 47, 13--37.

Ross, Stephen A., 1976, The arbitrage theory of capital asset pricing, Journal of Economic Theory 13, 341-360.

Shanken, Jay, 1990, Intertemporal asset pricing: An empirical investigation, Journal of Econometrics 45, 99--120. 
Sharpe, William, 1964, Capital asset prices: A theory of market equilibrium under conditions of risk, Journal of Finance 19, 425--442.

Solnik, Bruno, 1974, An equilibrium model of the international capital market, Journal of Economic Theory 8, 500--524.

Solnik, Bruno, 1974b The international pricing of risk: An empirical investigation of the world capital market structure, Journal of Finance 29, 48--54.

Solnik, Bruno, 1977, Testing international asset pricing: Some pessimistic views, Journal of Finance 32 (1977), 503--511.

Solnik, Bruno, 1983, The relationship between stock prices and inflationary expectations: The international evidence, Journal of Finance 38, 35--48.

Solnik, Bruno, 1983, International arbitrage pricing theory, Journal of Finance 38, 449--457.

Stambaugh, Robert F., 1982, On the exclusion of assets from tests of the two parameter model: A sensitivity analysis, Journal of Financial Economics 10, 237-268.

Stehle, Richard, 1977, An empirical test of the alternative hypotheses of national and international pricing of risky assets, Journal of Finance 32, 493--502.

Stulz, Rene, 1981a, On the effects of barriers to international investment, Journal of Finance 36, 923-934.

Stulz, Rene, 1981b, A model of international asset pricing, Journal of Financial Economics 9, 383-406.

World Bank, 1993, Emerging stock markets factbook, (International Finance Corporation, Washington, D.C.). 
Table 1

Critical Factors in Institutional Investor's Country Credit Risk Ratings

\begin{tabular}{l|rrrr|rr}
\hline & OECD & \multicolumn{2}{c}{ Emerging } & \multicolumn{2}{c}{ Rest of World } \\
& 1979 & 1994 & 1979 & 1994 & 1979 & 1994 \\
\hline Economic Outlook & 1 & 1 & 2 & 3 & 3 & 4 \\
Debt Service & 5 & 2 & 1 & 1 & 1 & 1 \\
Financial Reserves/Current Account & 2 & 3 & 4 & 4 & 4 & 3 \\
Fiscal Policy & 9 & 4 & 9 & 7 & 6 & 6 \\
Political Outlook & 3 & 5 & 3 & 2 & 2 & 2 \\
Access to Capital Markets & 6 & 6 & 7 & 9 & 8 & 9 \\
Trade Balance & 4 & 7 & 5 & 5 & 5 & 5 \\
Inflow of Portfolio Investment & 7 & 8 & 8 & 8 & 7 & 8 \\
Foreign Direct Investment & 8 & 9 & 6 & 6 & 9 & 7 \\
\hline
\end{tabular}

24 Erb-Harvey-Viskanta--Political Risk, Economic Risk and Financial Risk: May 6, 1996. 
Table 2

Critical Factors in the ICRG Rating System

Political

Economic expectations vs. reality

Economic planning failures

Political leadership

External conflict

Corruption in government

Military in politics

Organized religion in politics

Law and order tradition

Racial and nationality tensions

Political terrorism

Civil war

Political party development

Quality of the Bureaucracy

\begin{tabular}{|c|c|c|}
\hline Points & $\begin{array}{c}\% \text { of } \\
\text { Individual } \\
\text { Index }\end{array}$ & $\begin{array}{c}\text { \% of } \\
\text { Composite }\end{array}$ \\
\hline 12 & $12 \%$ & $6 \%$ \\
\hline 12 & $12 \%$ & $6 \%$ \\
\hline 12 & $12 \%$ & $6 \%$ \\
\hline 10 & $10 \%$ & $5 \%$ \\
\hline 6 & $6 \%$ & $3 \%$ \\
\hline 6 & $6 \%$ & $3 \%$ \\
\hline 6 & $6 \%$ & $3 \%$ \\
\hline 6 & $6 \%$ & $3 \%$ \\
\hline 6 & $6 \%$ & $3 \%$ \\
\hline 6 & $6 \%$ & $3 \%$ \\
\hline 6 & $6 \%$ & $3 \%$ \\
\hline 6 & $6 \%$ & $3 \%$ \\
\hline 6 & $6 \%$ & $3 \%$ \\
\hline 100 & $100 \%$ & $50 \%$ \\
\hline
\end{tabular}

Total Political Points

Financial

Loan Default or unfavorable loan restructuring

Delayed payment of suppliers' credits

Repudiation of contracts by governments

Losses from exchange controls

Expropriation of private investments

$\begin{array}{lll}10 & 20 \% & 5 \% \\ 10 & 20 \% & 5 \% \\ 10 & 20 \% & 5 \% \\ 10 & 20 \% & 5 \% \\ 10 & 20 \% & 5 \%\end{array}$

Total Financial Points

50

$100 \%$

$25 \%$

\section{Economic}

Inflation

Debt service as a \% of exports of goods and services

International liquidity ratios

Foreign trade collection experience

Current account balance as a $\%$ of goods and services

Parallel foreign exchange rate market indicators

Total Economic Points

50

$\begin{array}{rrr}10 & 20 \% & 5 \% \\ 10 & 20 \% & 5 \% \\ 5 & 10 \% & 3 \% \\ 5 & 10 \% & 3 \% \\ 15 & 30 \% & 8 \% \\ 5 & 10 \% & 3 \% \\ 50 & 100 \% & 25 \%\end{array}$

25 Erb-Harvey-Viskanta--Political Risk, Economic Risk and Financial Risk: May 6, 1996. 
Table 3

ICRG Risk Categories

\begin{tabular}{ll}
\hline Risk Category & Composite Score Range \\
\hline Very High Risk & $0.0-49.5$ \\
High Risk & $50.0-59.5$ \\
Moderate Risk & $60.0-69.5$ \\
Low Risk & $70.0-84.5$ \\
Very Low Risk & $85.0-100.0$ \\
\hline
\end{tabular}

26 Erb-Harvey-Viskanta--Political Risk, Economic Risk and Financial Risk: May 6, 1996. 
Table 4

Comparison of Sovereign Country Ratings and Other Risk Attributes in October 1995

\begin{tabular}{|c|c|c|c|c|c|c|c|}
\hline Country & $S \& P$ & Moody's & II CCR & ICRGC & ICRGP & ICRGF & ICRGE \\
\hline Argentina & BB- & B1 & 38.8 & 70.0 & 74.0 & 34.0 & 31.5 \\
\hline Australia & AA & Aa2 & 71.2 & 82.5 & 83.0 & 44.0 & 37.5 \\
\hline Austria & AAA & Aaa & 86.2 & 84.0 & 81.0 & 47.0 & 39.5 \\
\hline Belgium & $\mathrm{AA}+$ & Aa1 & 79.2 & 83.0 & 79.0 & 46.0 & 41.0 \\
\hline Brazil & $B+$ & B1 & 34.9 & 62.5 & 64.0 & 33.0 & 28.0 \\
\hline Canada & AA+ & Aa2 & 80.3 & 83.0 & 81.0 & 46.0 & 39.0 \\
\hline Chile & A- & Baa1 & 57.4 & 79.5 & 74.0 & 43.0 & 42.0 \\
\hline Colombia & BBB- & Baa3 & 46.5 & 68.0 & 60.0 & 40.0 & 35.5 \\
\hline Czech Republic & $A$ & Baa1 & 58.4 & 82.0 & 80.0 & 42.0 & 41.5 \\
\hline Denmark & AA+ & Aa1 & 79.9 & 87.5 & 84.0 & 48.0 & 42.5 \\
\hline Finland & AA- & $\mathrm{Aa} 2$ & 71.4 & 84.5 & 87.0 & 43.0 & 39.0 \\
\hline France & AAA & Aaa & 89.1 & 82.0 & 80.0 & 44.0 & 40.0 \\
\hline Germany & AAA & Aaa & 90.9 & 84.5 & 83.0 & 47.0 & 39.0 \\
\hline Greece & BBB- & Baa3 & 50.0 & 75.0 & 75.0 & 38.0 & 36.5 \\
\hline Hong Kong & A & A3 & 67.0 & 81.0 & 72.0 & 46.0 & 43.5 \\
\hline Hungary & $\mathrm{BB}+$ & Ba1 & 45.0 & 72.5 & 78.0 & 39.0 & 28.0 \\
\hline India & $\mathrm{BB}+$ & Baa3 & 46.1 & 69.0 & 63.0 & 37.0 & 37.5 \\
\hline Indonesia & BBB & Baa3 & 52.4 & 69.5 & 63.0 & 39.0 & 37.0 \\
\hline Ireland & AA & Aa2 & 73.4 & 84.0 & 85.0 & 44.0 & 38.5 \\
\hline Italy & AA & A1 & 72.3 & 77.0 & 75.0 & 41.0 & 38.0 \\
\hline Japan & AAA & Aaa & 91.6 & 86.0 & 80.0 & 48.0 & 44.0 \\
\hline Malaysia & $A+$ & A1 & 69.1 & 80.5 & 76.0 & 43.0 & 42.0 \\
\hline Mexico & BB & $\mathrm{Ba} 2$ & 41.8 & 66.0 & 65.0 & 37.0 & 30.0 \\
\hline Netherlands & AAA & Aaa & 89.3 & 86.0 & 84.0 & 47.0 & 40.5 \\
\hline New Zealand & $A A$ & Aa2 & 69.4 & 83.5 & 84.0 & 46.0 & 36.5 \\
\hline Nigeria & NR & NR & 15.8 & 52.5 & 52.0 & 26.0 & 26.5 \\
\hline Norway & AAA & Aa1 & 81.6 & 87.0 & 83.0 & 46.0 & 44.5 \\
\hline Pakistan & $\mathrm{B}+$ & B1 & 30.7 & 59.5 & 54.0 & 33.0 & 31.5 \\
\hline Peru & NR & NR & 25.8 & 60.0 & 56.0 & 31.0 & 33.0 \\
\hline Philippines & BB & $\mathrm{Ba} 2$ & 36.8 & 67.5 & 62.0 & 37.0 & 35.5 \\
\hline Poland & BB & Baa3 & 37.6 & 78.0 & 79.0 & 40.0 & 37.0 \\
\hline Portugal & AA- & $\mathrm{A} 1$ & 68.4 & 80.0 & 75.0 & 43.0 & 41.5 \\
\hline Singapore & AAA & Aa2 & 84.0 & 86.0 & 80.0 & 48.0 & 44.0 \\
\hline South Africa & $\mathrm{BB}+$ & Baa3 & 45.2 & 76.5 & 75.0 & 41.0 & 36.5 \\
\hline South Korea & AA- & A1 & 72.2 & 82.0 & 77.0 & 46.0 & 41.0 \\
\hline Spain & AA & Aa2 & 73.7 & 74.0 & 69.0 & 41.0 & 38.0 \\
\hline Sweden & $\mathrm{AA}+$ & Aa3 & 74.1 & 82.0 & 81.0 & 43.0 & 39.5 \\
\hline Switzerland & AAA & Aaa & 92.2 & 89.0 & 85.0 & 50.0 & 43.0 \\
\hline Taiwan & AA+ & Aa3 & 79.9 & 84.5 & 77.0 & 48.0 & 44.0 \\
\hline Thailand & $A$ & $\mathrm{~A} 2$ & 63.8 & 77.0 & 69.0 & 43.0 & 41.5 \\
\hline Turkey & $\mathrm{B}+$ & $\mathrm{Ba3}$ & 40.9 & 62.5 & 59.0 & 36.0 & 30.0 \\
\hline United Kingdom & AAA & Aaa & 87.8 & 79.5 & 78.0 & 46.0 & 35.0 \\
\hline USA & AAA & Aaa & 90.7 & 83.0 & 80.0 & 48.0 & 38.0 \\
\hline Venezuela & $\mathrm{B}+$ & $\mathrm{Ba} 2$ & 31.4 & 66.5 & 65.0 & 34.0 & 34.0 \\
\hline Zimbabwe & NR & NR & 31.0 & 64.5 & 66.0 & 31.0 & 31.5 \\
\hline \multicolumn{3}{|c|}{$\overline{S \& P}$ Rank Correlation } & $95.2 \%$ & $87.6 \%$ & $77.0 \%$ & $90.2 \%$ & $72.4 \%$ \\
\hline \multicolumn{3}{|c|}{ Moody's Rank Correlation } & $95.1 \%$ & $87.5 \%$ & $79.5 \%$ & $89.8 \%$ & $67.6 \%$ \\
\hline
\end{tabular}

Legend

\begin{tabular}{ll}
\hline II CCR & Institutional Investor Country Credit Ratings \\
ICRGC & International Country Risk Guide Composite Index \\
ICRGP & International Country Risk Guide Political Index \\
ICRGF & International Country Risk Guide Financial Index \\
ICRGE & International Country Risk Guide Economic Index \\
\hline
\end{tabular}


Table 5

Summary Analysis of Country Risk Measures

Semi-Annual Observations: January 1984-July 1995

A. Correlation of Risk Measures

\begin{tabular}{l|rrrrr} 
& & & \multicolumn{4}{c}{ Risk Measure Changes } \\
& II CCR & ICRGC & ICRGP & ICRGF & ICRGE \\
\hline II CCR & & -0.03 & 0.01 & 0.03 & -0.09 \\
ICRGC & 0.35 & & 0.79 & 0.54 & 0.43 \\
ICRGP & 0.30 & 0.83 & & 0.25 & 0.06 \\
ICRGF & 0.26 & 0.60 & 0.35 & & 0.05 \\
ICRGE & 0.10 & 0.52 & 0.24 & 0.25 & \\
\cline { 2 - 7 }
\end{tabular}

Risk Measure Levels

B. Persistence of Risk Measures

First Order Autocorrelations of Log Rating Changes

\begin{tabular}{lrrrrr} 
& \multicolumn{2}{c}{ All Countries } & \multicolumn{3}{c}{ Developed Emerging } \\
& Average & Minimum & Maximum & Average & Average \\
\hline II CCR & 0.24 & -0.31 & 0.77 & 0.20 & 0.26 \\
ICRGC & 0.04 & -0.92 & 0.93 & -0.01 & 0.07 \\
ICRGP & -0.01 & -0.84 & 0.51 & 0.03 & -0.04 \\
ICRGF & 0.10 & -0.60 & 0.75 & 0.08 & 0.11 \\
ICRGE & -0.18 & -0.72 & 0.67 & -0.17 & -0.19 \\
\hline
\end{tabular}

C. Sample Period Correlation Between Average Risk Measures and Price Moments

\begin{tabular}{llrrrrr}
$\begin{array}{l}\text { Country } \\
\text { Sample }\end{array}$ & Price Moment & & & & & \\
\hline All & Geometric Return & -0.23 & -0.15 & -0.13 & -0.16 & -0.16 \\
Countries & Volatility & -0.52 & -0.45 & -0.31 & -0.49 & -0.59 \\
& Beta - MSCI World & 0.24 & 0.43 & 0.44 & 0.40 & 0.30 \\
Developed & Geometric Return & 0.18 & -0.15 & -0.28 & -0.08 & 0.21 \\
& Volatility & -0.46 & -0.41 & -0.38 & -0.47 & -0.15 \\
& Beta - MSCI World & 0.09 & -0.15 & -0.24 & -0.04 & 0.06 \\
Emerging & Geometric Return & -0.26 & -0.06 & -0.02 & -0.08 & -0.12 \\
& Volatility & -0.16 & -0.08 & 0.20 & -0.16 & -0.45 \\
& Beta-MSCI World & 0.03 & 0.42 & 0.46 & 0.35 & 0.20 \\
\hline
\end{tabular}

Legend

II CCR Institutional Investor Country Credit Ratings

ICRGC International Country Risk Guide Composite Index

ICRGP International Country Risk Guide Political Index

ICRGF International Country Risk Guide Financial Index

ICRGE International Country Risk Guide Economic Index 
Table 6

Predicting Changes in Risk Attributes

A. Country Risk Guide Attributes as a Predictor of Institutional Investor Country Credit Ratings

\begin{tabular}{lrrr}
\multicolumn{1}{c}{ Attribute } & Coefficient & \multicolumn{1}{c}{ T-Stat } & R-Square \\
\hline ICRGC & 0.2120 & 7.59 & $5.0 \%$ \\
ICRGP & 0.1244 & 5.67 & $2.8 \%$ \\
ICRGF & 0.0956 & 5.69 & $2.8 \%$ \\
ICRGE & 0.0833 & 4.65 & $1.9 \%$ \\
\hline
\end{tabular}

B. Institutional Investor Country Credit Ratings as

a Predictor of Country Risk Guide Attributes

\begin{tabular}{lrrr}
\multicolumn{1}{c}{ Attribute } & Coefficient & \multicolumn{1}{c}{ T-Stat } & R-Square \\
\hline ICRGC & -0.0115 & -1.13 & $0.1 \%$ \\
ICRGP & -0.0087 & -0.62 & $0.0 \%$ \\
ICRGF & -0.0585 & -4.09 & $1.4 \%$ \\
ICRGE & -0.0198 & -0.99 & $0.0 \%$ \\
\hline
\end{tabular}

In Panel A, the semi-annual log change in the II CCR is regressed on the lagged semi-annual log changes of the ICRG ratings.

The sample is from March 1984 through October 1995 for countries with equity markets.

In Panel $\mathrm{B}$, the monthly log change in the ICRG ratings are regressed on the lagged semi-annual log change in the II CCR.

The sample is from February 1984 through September 1995 for countries with equity markets.

Legend

II CCR Institutional Investor Country Credit Ratings

ICRGC International Country Risk Guide Composite Index

ICRGP International Country Risk Guide Political Index

ICRGF International Country Risk Guide Financial Index

ICRGE International Country Risk Guide Economic Index 
Table 8

Cross-Sectional Time-Series Importance of Country Risk Attributes

A. Lagged Level Regressions

\begin{tabular}{|c|c|c|c|c|c|c|c|c|c|c|c|c|}
\hline Sample & Regression & II CCR & R-Sqr & ICRGC & R-Sqr & ICRGP & R-Sqr & ICRGF & R-Sqr & ICRGE & R-Sqr & R-Sqr \\
\hline$\overline{\text { Full }}$ & Univariate & -0.0011 ** & $0.5 \%$ & 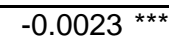 & $0.7 \%$ & $-0.0017^{\star *}$ & $0.4 \%$ & $-0.0043^{\star \star \star}$ & $1.2 \%$ & -0.0041 ** & $0.4 \%$ & \\
\hline Full & Multivariate & 0.0003 & & & & 0.0016 & & $-0.0082 * \star \star *$ & & 0.0024 & & $1.1 \%$ \\
\hline Developed & Univariate & -0.0007 & $-0.1 \%$ & -0.0019 & $0.0 \%$ & -0.0007 & $-0.2 \%$ & $-0.0107 * * \star$ & $3.2 \%$ & 0.0071 ** & $0.8 \%$ & \\
\hline Developed & Multivariate & 0.0027 * & & & & 0.0000 & & $-0.0184 * * \star$ & & $0.0109 * \star \star$ & & $6.3 \%$ \\
\hline Emerging & Univariate & -0.0009 & $-0.2 \%$ & -0.0023 & $0.1 \%$ & -0.0011 & $-0.2 \%$ & -0.0035 & $0.2 \%$ & -0.0050 & $0.2 \%$ & \\
\hline Emerging & Multivariate & 0.0015 & & & & 0.0011 & & -0.0046 & & -0.0042 & & $-0.4 \%$ \\
\hline
\end{tabular}

B. Lagged Change in Level Regressions

\begin{tabular}{|c|c|c|c|c|c|c|c|c|c|c|c|c|}
\hline Sample & Regression & II CCR & R-Sqr & ICRGC & R-Sqr & ICRGP & R-Sqr & ICRGF & R-Sqr & ICRGE & R-Sqr & R-Sqr \\
\hline$\overline{\text { Full }}$ & Univariate & -0.0072 & $-0.1 \%$ & -0.0046 & $0.0 \%$ & -0.0076 * & $0.3 \%$ & -0.0015 & $-0.1 \%$ & 0.0071 & $0.0 \%$ & \\
\hline Full & Multivariate & -0.0037 & & & & -0.0096 ** & & 0.0050 & & 0.0092 & & $0.2 \%$ \\
\hline Developed & Univariate & 0.0072 & $-0.1 \%$ & -0.0014 & $-0.2 \%$ & -0.0012 & $-0.2 \%$ & -0.0181 * & $0.6 \%$ & 0.0051 & $-0.1 \%$ & \\
\hline Developed & Multivariate & 0.0097 & & & & -0.0032 & & -0.0188 * & & 0.0049 & & $0.2 \%$ \\
\hline Emerging & Univariate & -0.0147 & $0.0 \%$ & -0.0089 & $0.1 \%$ & $-0.0135 * *$ & $0.9 \%$ & -0.0008 & $-0.3 \%$ & -0.0019 & $-0.2 \%$ & \\
\hline Emerging & Multivariate & -0.0147 & & & & $-0.0185 * *$ & & 0.0123 & & 0.0097 & & $0.8 \%$ \\
\hline
\end{tabular}

Significance level: * $10 \%, * * 5 \%, * \star * 1 \%$.

Panel A results from time-series cross-sectional regressions of semi-annual returns against the lagged risk attribute, or in the multivariate case, risk attributes. Panel B results from time-series cross-sectional regressions of semi-annual returns against the lagged log change in the risk attribute, or in the multivariate case, risk attributes.

\begin{tabular}{ll} 
Legend & \\
\hline II CCR & Institutional Investor Country Credit Ratings \\
ICRGC & International Country Risk Guide Composite Index \\
ICRGP & International Country Risk Guide Political Index \\
ICRGF & International Country Risk Guide Financial Index \\
ICRGE & International Country Risk Guide Economic Index \\
\hline
\end{tabular}


Table 9

The Relationship Between Fundamental Variables and Risk Attributes

\begin{tabular}{|c|c|c|c|c|c|c|c|c|c|c|c|c|c|}
\hline Sample & Regression & $\begin{array}{l}\text { Fundamental } \\
\text { Variable }\end{array}$ & II CCR & R-Sqr & ICRGC & R-Sqr & ICRGP & R-Sqr & ICRGF & R-Sqr & ICRGE & R-Sqr & R-Sqr \\
\hline \multirow[t]{3}{*}{ Full } & Univariate & Book/Price & $-0.0066^{\star \star \star}$ & $5.0 \%$ & $-0.0126^{* \star *}$ & $5.7 \%$ & -0.0048 *** & $0.8 \%$ & $-0.0229^{* \star *}$ & $8.4 \%$ & $-0.0525 * \star \star$ & $18.5 \%$ & \\
\hline & & Dividend/Price & $-0.0169 * \star \star \star$ & $3.2 \%$ & $-0.0448 * \star \star$ & $7.1 \%$ & -0.0351 *** & $5.0 \%$ & 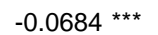 & $7.3 \%$ & -0.1034 *** & $6.9 \%$ & \\
\hline & & Earnings/Price & -0.0009 *** & $6.2 \%$ & $-0.0019 * * *$ & $8.3 \%$ & -0.0013 *** & $4.3 \%$ & 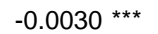 & $9.3 \%$ & $-0.0054 * \star * *$ & $12.3 \%$ & \\
\hline \multirow[t]{3}{*}{ Full } & Multivariate & Book/Price & 0.0042 ** & & & & $0.0191 * \star \star *$ & & 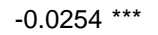 & & $-0.0656 * \star \star *$ & & $25.1 \%$ \\
\hline & & Dividend/Price & $0.0309 * * *$ & & & & -0.0204 * & & $-0.0660 * * *$ & & $-0.0921 * \star * *$ & & $9.8 \%$ \\
\hline & & Earnin & 0.0005 * & & & & 0.0005 & & $-0.0023 * \star *$ & & $-0.0050 * * *$ & & $13.1 \%$ \\
\hline \multirow[t]{3}{*}{ Developed } & Univariate & Book/Price & -0.0099 & $11.4 \%$ & $-0.0155 * * *$ & $9.2 \%$ & -0.0058 *** & $2.1 \%$ & -0.0270 *** & $12.2 \%$ & $-0.0299 * \star *$ & $10.4 \%$ & \\
\hline & & Dividend/Price & -0.0507 *** & $7.6 \%$ & $-0.1097 * \star \star$ & $11.8 \%$ & -0.0602 *** & $6.2 \%$ & $-0.1134 * \star \star$ & $5.4 \%$ & $-0.2093 * \star \star$ & $13.1 \%$ & \\
\hline & & Earnings/Price & -0.0002 & $0.1 \%$ & -0.0001 & $-0.2 \%$ & 0.0003 & $0.1 \%$ & -0.0006 & $0.1 \%$ & $-0.0019 * \star *$ & $1.9 \%$ & \\
\hline \multirow[t]{3}{*}{ Developed } & Multivariate & Book/l & -0.0047 ** & & & & 0.00 & & $64 * * *$ & & $-0.0208 * * *$ & & $18.2 \%$ \\
\hline & & Divid & -0.0 & & & & -0.0 & & -0 . & & $13 * \star \star$ & & $15.6 \%$ \\
\hline & & Drice & -0.0002 & & & & $0.0008 * * *$ & & -0.0004 & & $-0.0021 * * *$ & & $3.0 \%$ \\
\hline \multirow[t]{3}{*}{ Emerging } & Univariate & Book/Price & -0.0159 *** & $6.8 \%$ & $-0.0220 * * *$ & $6.3 \%$ & -0.0013 & $-0.3 \%$ & -0.0348 *** & $9.2 \%$ & $-0.0775 * * *$ & $23.6 \%$ & \\
\hline & & Dividend/Price & -0.0562 *** & $10.8 \%$ & -0.1018 *** & $17.5 \%$ & 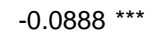 & $13.3 \%$ & -0.1298 *** & $16.4 \%$ & -0.1353 & $8.9 \%$ & \\
\hline & & Earnings/Price & $-0.0018 * \star * *$ & $5.9 \%$ & $-0.0032 * \star \star *$ & $8.8 \%$ & -0.0019 *** & $3.1 \%$ & -0.0042 *** & $8.8 \%$ & $-0.0069 * \star \star$ & $12.2 \%$ & \\
\hline \multirow[t]{3}{*}{ Emerging } & Multivariate & Book/Price & 0.0105 ** & & & & $0.0248 * \star \star *$ & & 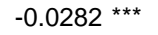 & & 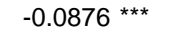 & & $28.7 \%$ \\
\hline & & Dividend/Price & -0.0136 & & & & -0.0388 ** & & $-0.0679 * \star$ & & -0.0125 & & $17.2 \%$ \\
\hline & & Earnings/Price & 0.0006 & & & & -0.0001 & & -0.0016 & & $-0.0064 * * *$ & & $12.2 \%$ \\
\hline
\end{tabular}

Significance level: * $10 \%, * * 5 \%, * * * 1 \%$.

Results from time-series cross-sectional regressions of the fundamental variable against the lagged risk attribute, or in the multivariate case, risk attributes.

\begin{tabular}{ll} 
Legend & \\
\hline II CCR & Institutional Investor Country Credit Ratings \\
ICRGC & International Country Risk Guide Composite Index \\
ICRGP & International Country Risk Guide Political Index \\
ICRGF & International Country Risk Guide Financial Index \\
ICRGE & International Country Risk Guide Economic Index \\
\hline
\end{tabular}


Table 10

Incremental Contribution of Country Risk Attributes

\begin{tabular}{|c|c|c|c|c|c|c|c|c|c|c|c|c|c|}
\hline Sample & Regression & $\begin{array}{l}\text { Fundamental } \\
\text { Variable }\end{array}$ & II CCR & R-Sqr & ICRGC & R-Sqr & ICRGP & R-Sqr & ICRGF & R-Sqr & ICRGE & R-Sqr & R-Sqr \\
\hline Full & Univariate & Book/Price & -0.0007 & $1.9 \%$ & -0.0016 * & $2.0 \%$ & $-0.0014^{*}$ & $2.0 \%$ & -0.0030 ** & $2.3 \%$ & -0.0009 & $1.7 \%$ & \\
\hline Full & Multivariate & Book/Price & 0.0000 & & & & 0.0003 & & -0.0066 ** & & 0.0066 * & & $2.4 \%$ \\
\hline Developed & Univariate & Book/Price & 0.0006 & $2.3 \%$ & 0.0001 & $2.3 \%$ & 0.0000 & $2.3 \%$ & $-0.0084 * \star *$ & $4.1 \%$ & $0.0121 * * *$ & $5.0 \%$ & \\
\hline Developed & Multivariate & Book/Price & 0.0034 ** & & & & -0.0006 & & $-0.0162 * \star *$ & & $0.0137 * * *$ & & $8.7 \%$ \\
\hline Emerging & Univariate & Book/Price & 0.0000 & $1.1 \%$ & -0.0011 & $1.2 \%$ & -0.0010 & $1.2 \%$ & -0.0017 & $1.2 \%$ & -0.0008 & $1.1 \%$ & \\
\hline Emerging & Multivariate & Book/Price & 0.0010 & & & & -0.0003 & & -0.0027 & & 0.0002 & & $0.5 \%$ \\
\hline
\end{tabular}

Significance level: * $10 \%, * \star 5 \%, * * * 1 \%$.

Results from time-series cross-sectional regressions of semi-annual returns against the fundamental variable (book/price) and the lagged risk attribute, or in the multivariate case, risk attributes. Only results for risk attributes are reported.

Legend

II CCR Institutional Investor Country Credit Ratings

ICRGC International Country Risk Guide Composite Index

ICRGP International Country Risk Guide Political Index

ICRGF International Country Risk Guide Financial Index

ICRGE International Country Risk Guide Economic Index 
Table 11

Cross-Sectional Regression Results

Semi-Annual Returns: April 1984-September 1995

A. Semi-Annual Return vs. Risk Attribute

Average Ave Slope T-Stat Average \% Negative Intercept Coefficient

\begin{tabular}{lcrrrr} 
& Intercept Coefficient & \multicolumn{3}{c}{ R-Square Coefficient } \\
\hline II CCR & 0.2413 & -0.0018 & -2.36 & $8.2 \%$ & $65.2 \%$ \\
ICRGC & 0.3110 & -0.0025 & -1.76 & $7.6 \%$ & $65.2 \%$ \\
ICRGP & 0.2671 & -0.0019 & -1.67 & $6.1 \%$ & $69.6 \%$ \\
ICRGF & 0.2785 & -0.0038 & -1.50 & $8.9 \%$ & $56.5 \%$ \\
ICRGE & 0.3747 & -0.0069 & -2.02 & $8.3 \%$ & $56.5 \%$ \\
BP & 0.0344 & 0.1387 & 4.46 & $9.4 \%$ & $17.4 \%$ \\
\hline
\end{tabular}

B. Semi-Annual Return vs. Risk Attribute \& Book-to-Price

\section{Risk Attribute Book-to-Price}

Average Ave Slope T-Stat \% Negativ€ Ave Slope T-Stat \% Negativ€ Average Intercept Coefficient CoefficientCoefficient

\begin{tabular}{lcccccccc} 
& & \multicolumn{3}{c}{ CoefficientCoefficient } & \multicolumn{3}{c}{ Coefficient R-Square } \\
\hline CCR & 0.0869 & -0.0008 & -1.12 & $65.2 \%$ & 0.1227 & 3.89 & $17.4 \%$ & $16.1 \%$ \\
ICRGC & 0.1708 & -0.0017 & -1.22 & $65.2 \%$ & 0.1277 & 4.39 & $17.4 \%$ & $16.3 \%$ \\
ICRGP & 0.2132 & -0.0023 & -1.70 & $69.6 \%$ & 0.1294 & 4.02 & $21.7 \%$ & $16.1 \%$ \\
ICRGF & 0.0908 & -0.0014 & -0.61 & $52.2 \%$ & 0.1304 & 4.57 & $17.4 \%$ & $16.6 \%$ \\
ICRGE & 0.0420 & -0.0003 & -0.10 & $43.5 \%$ & 0.1347 & 4.75 & $17.4 \%$ & $15.9 \%$ \\
\hline
\end{tabular}

C. Semi-Annual Return vs. Adjusted Risk Attribute*

\begin{tabular}{|c|c|c|c|c|c|}
\hline & $\begin{array}{l}\text { Average } \\
\text { Intercept }\end{array}$ & $\begin{array}{l}\text { Ave Slope } \\
\text { Coefficient }\end{array}$ & -Stat & \multicolumn{2}{|c|}{$\begin{array}{l}\text { Average } \% \text { Negative } \\
\text { R-Square Coefficient }\end{array}$} \\
\hline$\overline{\mathrm{CCR}}$ & 0.0965 & 0.0401 & 1.26 & $17.9 \%$ & $39.1 \%$ \\
\hline ICRGC & 0.1055 & 0.0272 & 0.77 & $17.3 \%$ & $43.5 \%$ \\
\hline ICRGP & 0.0960 & 0.0446 & 1.37 & $16.0 \%$ & $43.5 \%$ \\
\hline ICRGF & 0.1030 & 0.0259 & 0.78 & $17.9 \%$ & $43.5 \%$ \\
\hline ICRGE & 0.1115 & 0.0196 & 0.59 & $18.9 \%$ & $47.8 \%$ \\
\hline BP & 0.0654 & 0.0683 & 2.05 & $24.0 \%$ & $30.4 \%$ \\
\hline
\end{tabular}

D. Semi-Annual Return vs. Risk Attribute \& Adjusted Risk Attribute

Risk Attribute

Adjusted Risk Attribute

Average Ave Slope T-Stat \% Negativ€ Ave Slope T-Stat \% Negativ€ Average

\begin{tabular}{lrrrrrrrr} 
& Intercept & Coefficient & \multicolumn{3}{c}{ Coefficient Coefficient } & \multicolumn{3}{c}{ Coefficient R-Square } \\
\hline CCR & 0.2280 & -0.0023 & -3.24 & $73.9 \%$ & 0.0494 & 1.56 & $30.4 \%$ & $26.0 \%$ \\
ICRGC & 0.3175 & -0.0031 & -2.18 & $60.9 \%$ & 0.0409 & 1.13 & $39.1 \%$ & $24.6 \%$ \\
ICRGP & 0.2832 & -0.0028 & -2.35 & $78.3 \%$ & 0.0537 & 1.60 & $34.8 \%$ & $22.6 \%$ \\
ICRGF & 0.2715 & -0.0047 & -1.96 & $60.9 \%$ & 0.0393 & 1.15 & $39.1 \%$ & $26.3 \%$ \\
ICRGE & 0.3618 & -0.0073 & -2.12 & $56.5 \%$ & 0.0292 & 0.88 & $52.2 \%$ & $26.3 \%$ \\
BP & -0.0037 & 0.0972 & 3.00 & $31.8 \%$ & 0.0701 & 2.01 & $36.4 \%$ & $31.7 \%$ \\
\hline
\end{tabular}

* Adjusted attributes are according to Ferson-Harvey methodology.

\begin{tabular}{ll} 
Legend & \\
\hline II CCR & Institutional Investor Country Credit Ratings \\
ICRGC & International Country Risk Guide Composite Index \\
ICRGP & International Country Risk Guide Political Index \\
ICRGF & International Country Risk Guide Financial Index \\
ICRGE & International Country Risk Guide Economic Index \\
BP & Book-to-Price Ratio \\
\hline
\end{tabular}




\section{Figure 1 \\ Analysis of Average Risk Ratings January 1984-July 1995}

\section{Equally Weighted Average for Developed Countries}

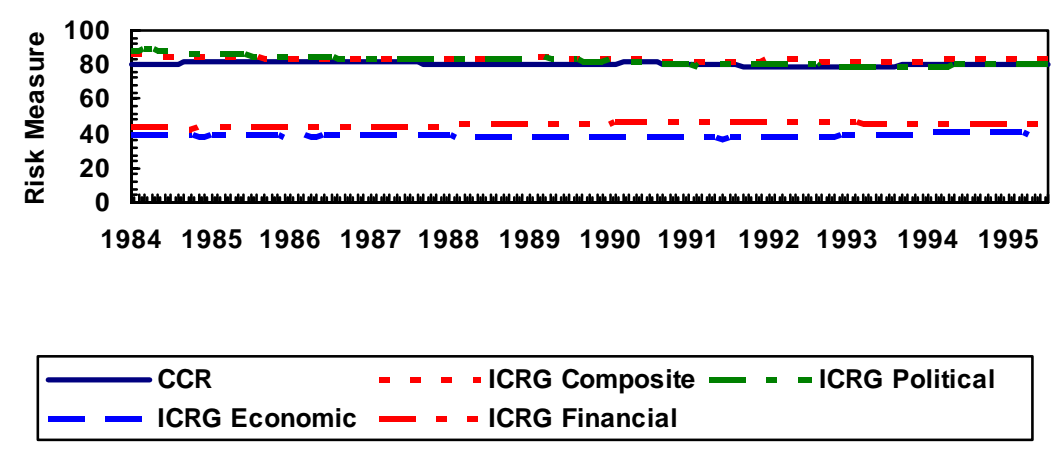

Equally Weighted Average for Emerging Countries

\begin{tabular}{|ll|}
\hline -CCR & - - - - ICRG Composite - - - ICRG Political \\
\hline - ICRG Economic & - - - ICRG Financial \\
\hline
\end{tabular}

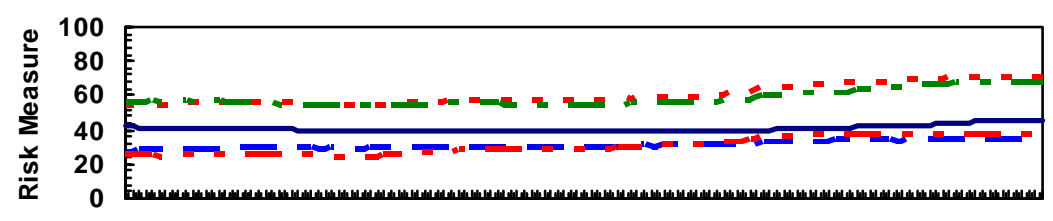

198419851986198719881989199019911992199319941995
Equally Weighted Average for All Other Countries
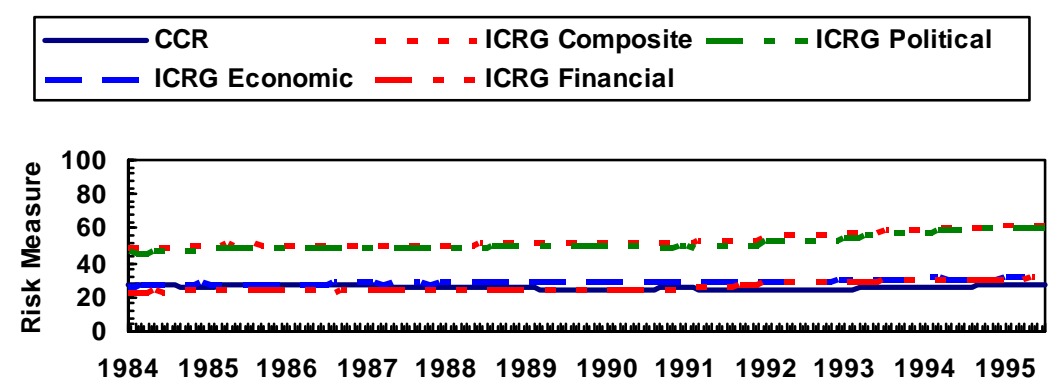
Figure 2

\section{Mean Reversion in Risk Levels}

\section{A. Institutional Investor Country Credit Rating}

Sample: Countries with Equity Markets

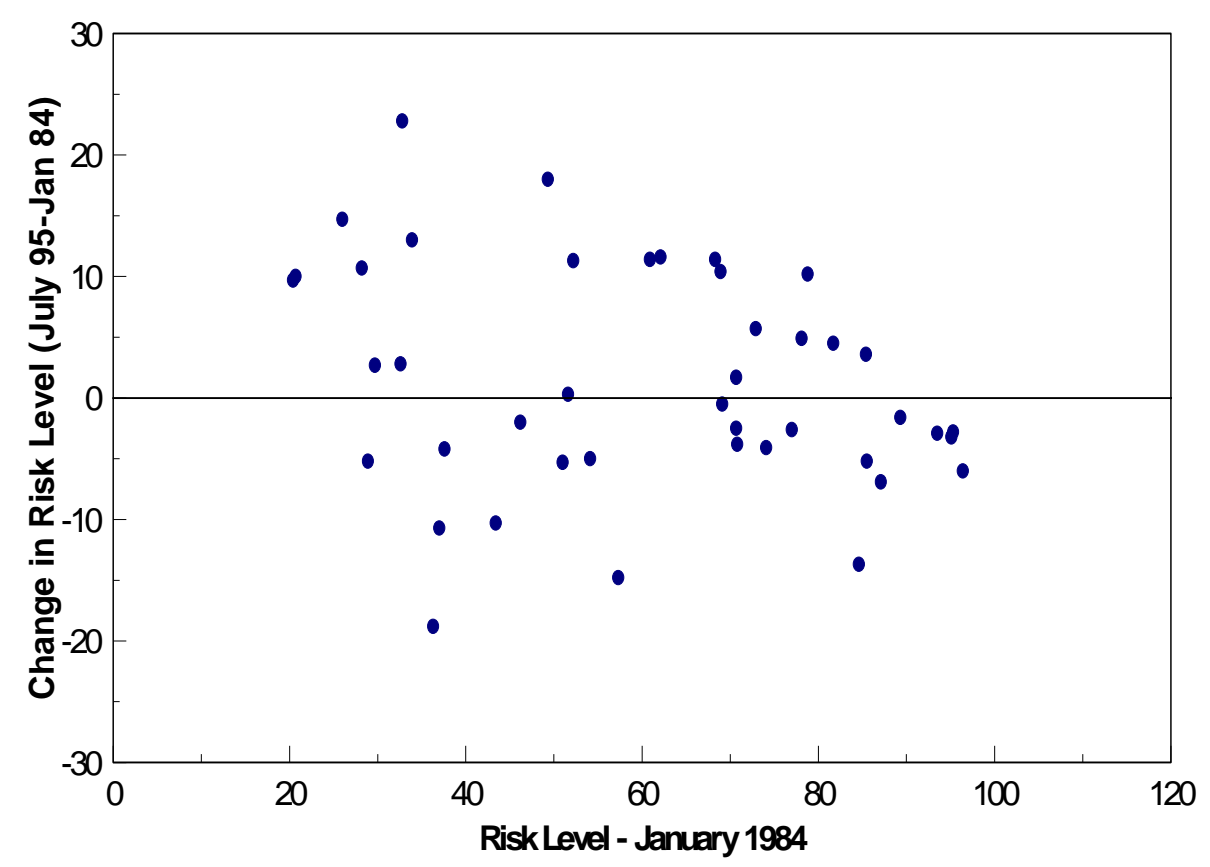

Sample: All Countries

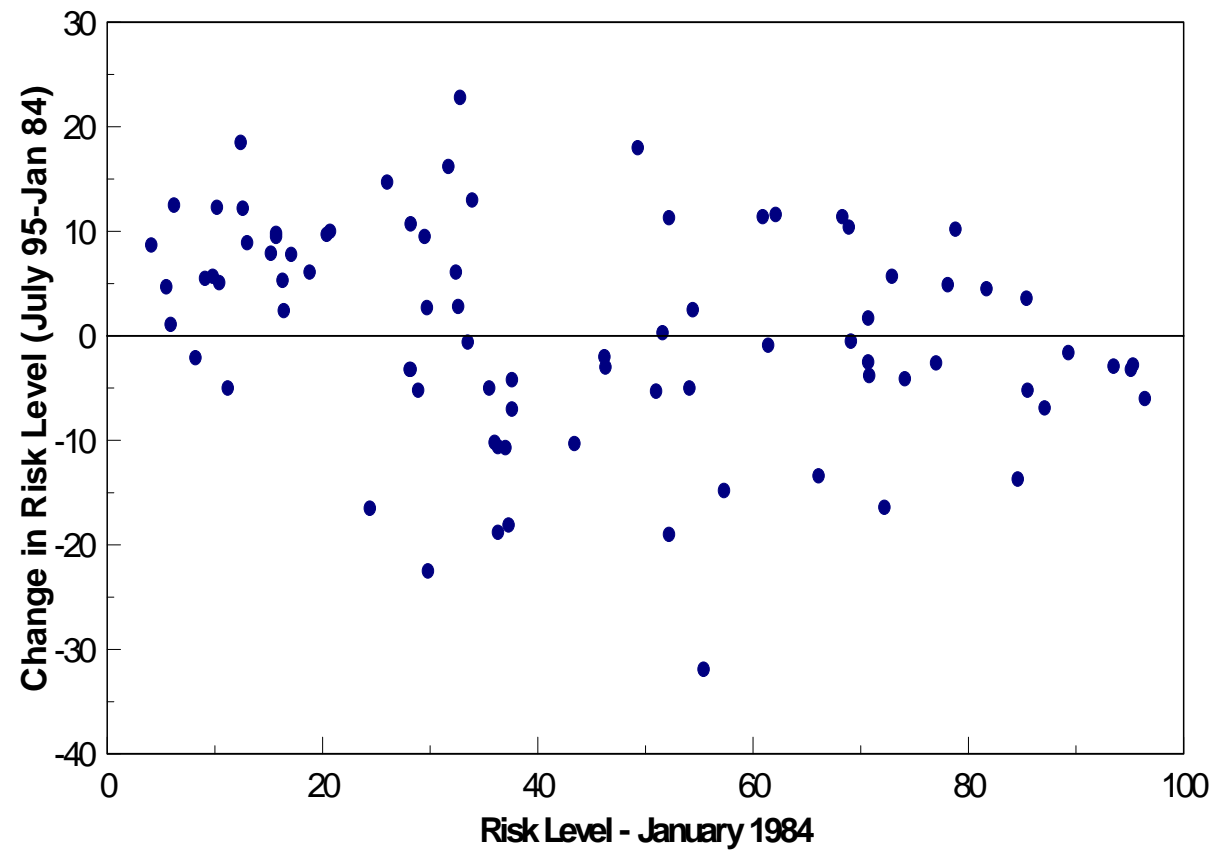


Figure 2

\section{Mean Reversion in Risk Levels}

\section{B. ICRG Composite Rating}

Sample: Countries with Equity Markets

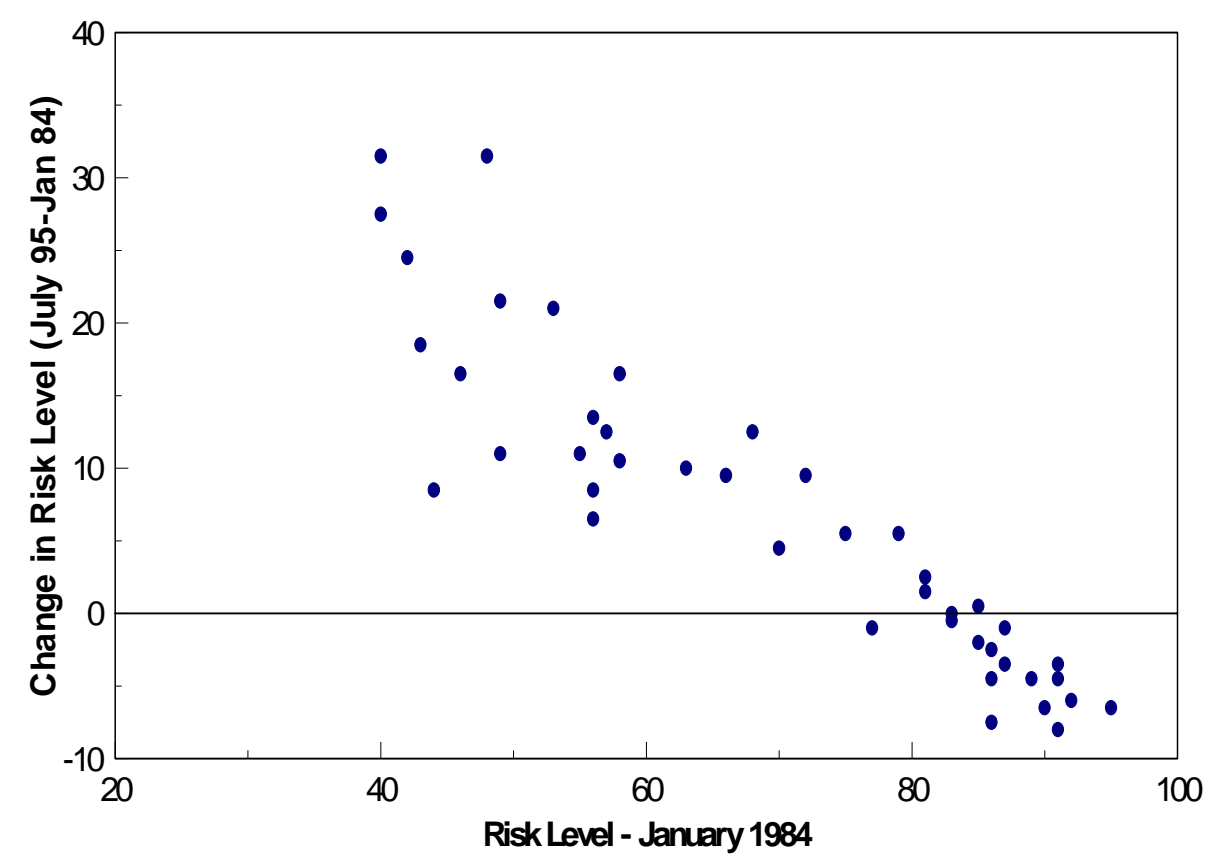

Sample: All Countries

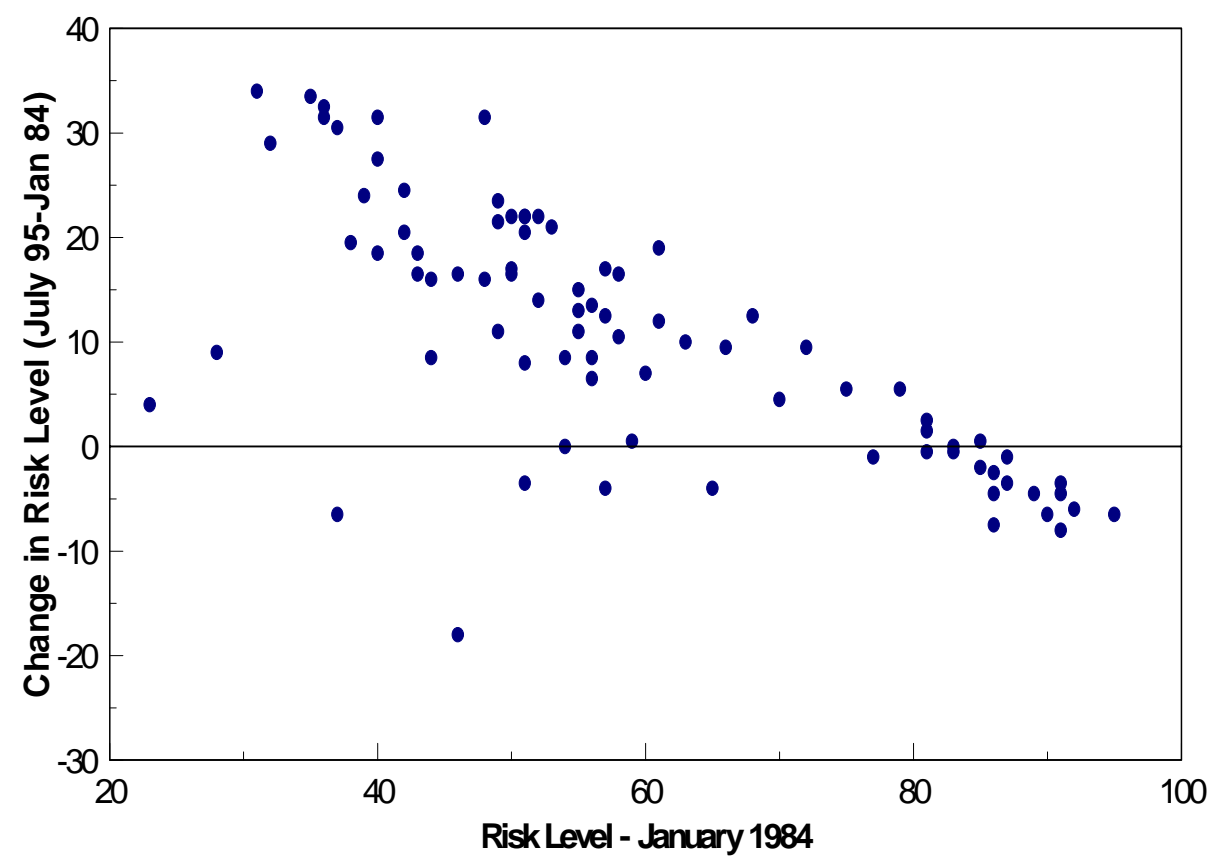


Figure 2

\section{Mean Reversion in Risk Levels}

\section{ICRG Political Rating}

Sample: Countries with Equity Markets

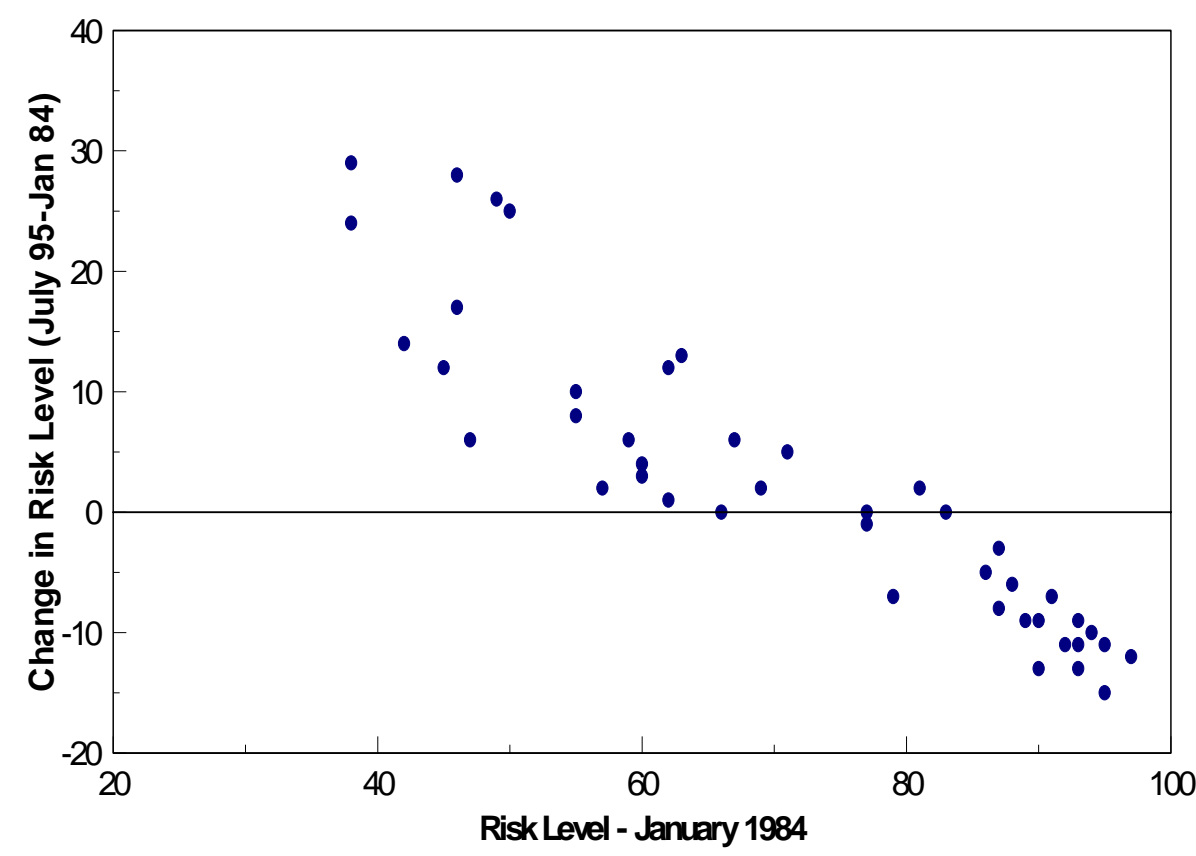

Sample: All Countries

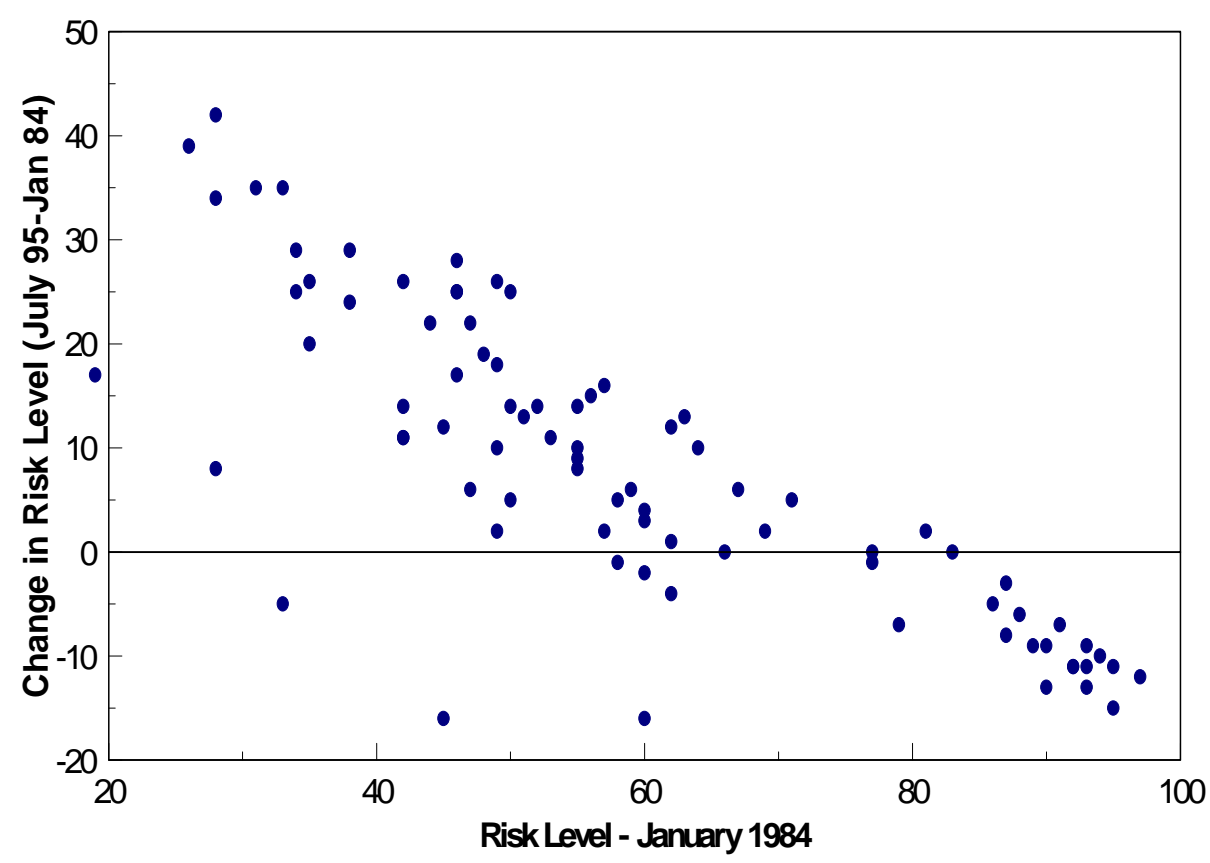


Figure 2

\section{Mean Reversion in Risk Levels}

\section{ICRG Financial Rating}

Sample: Countries with Equity Markets

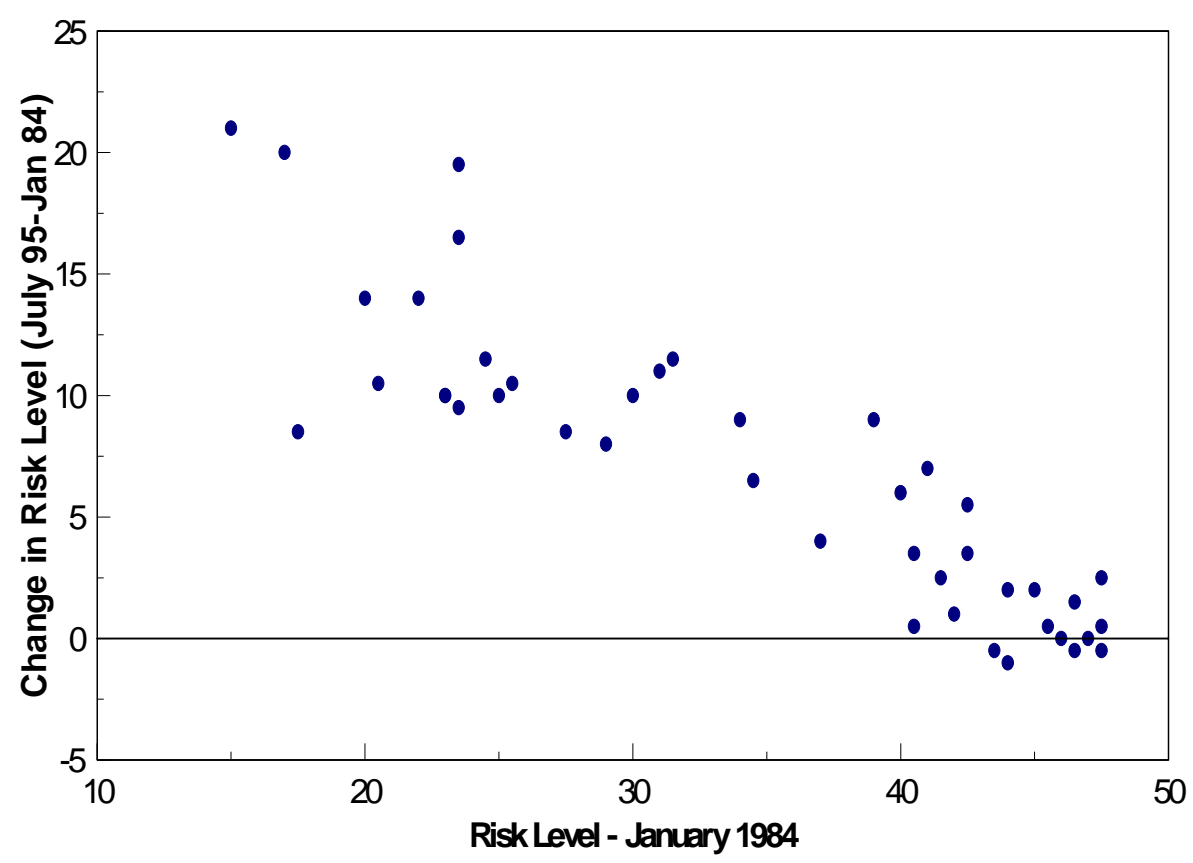

Sample: All Countries

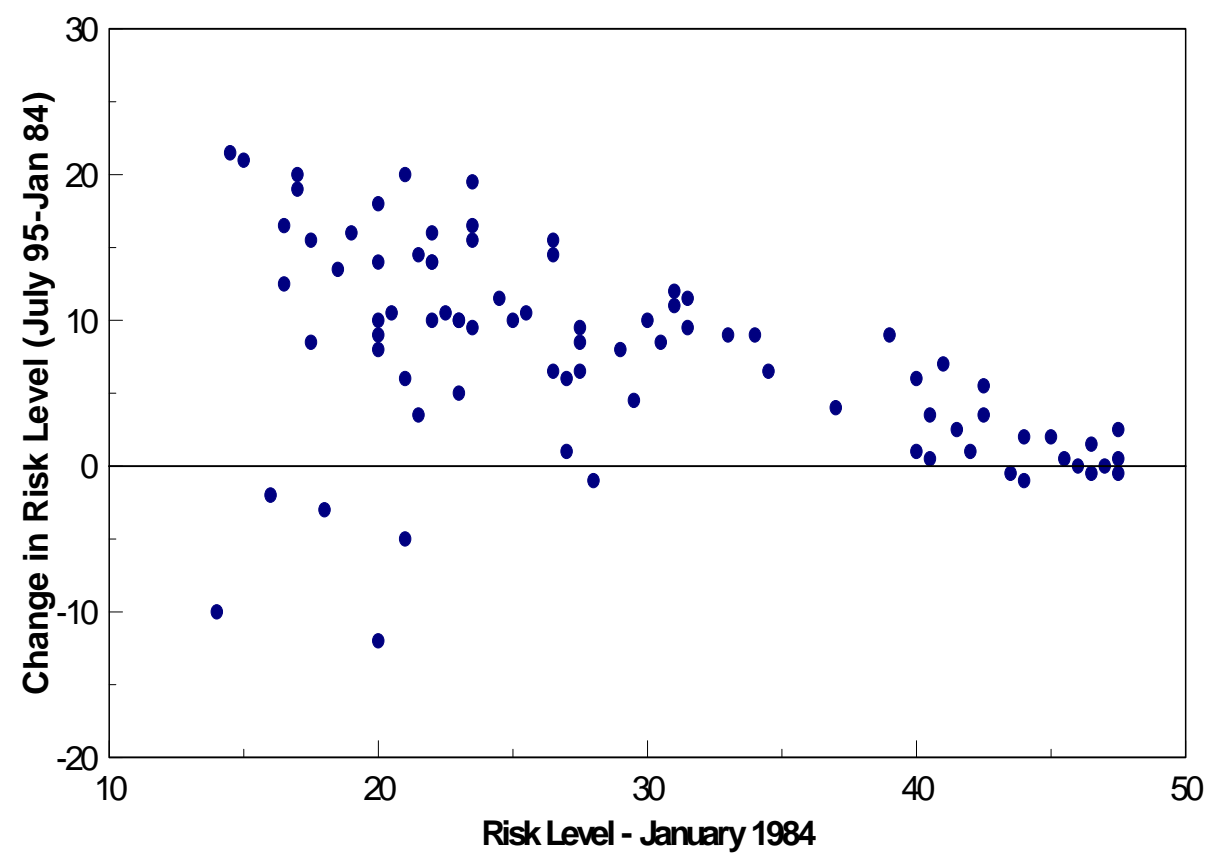


Figure 2

\section{Mean Reversion in Risk Levels}

\section{E. ICRG Economic Rating}

Sample: Countries with Equity Markets

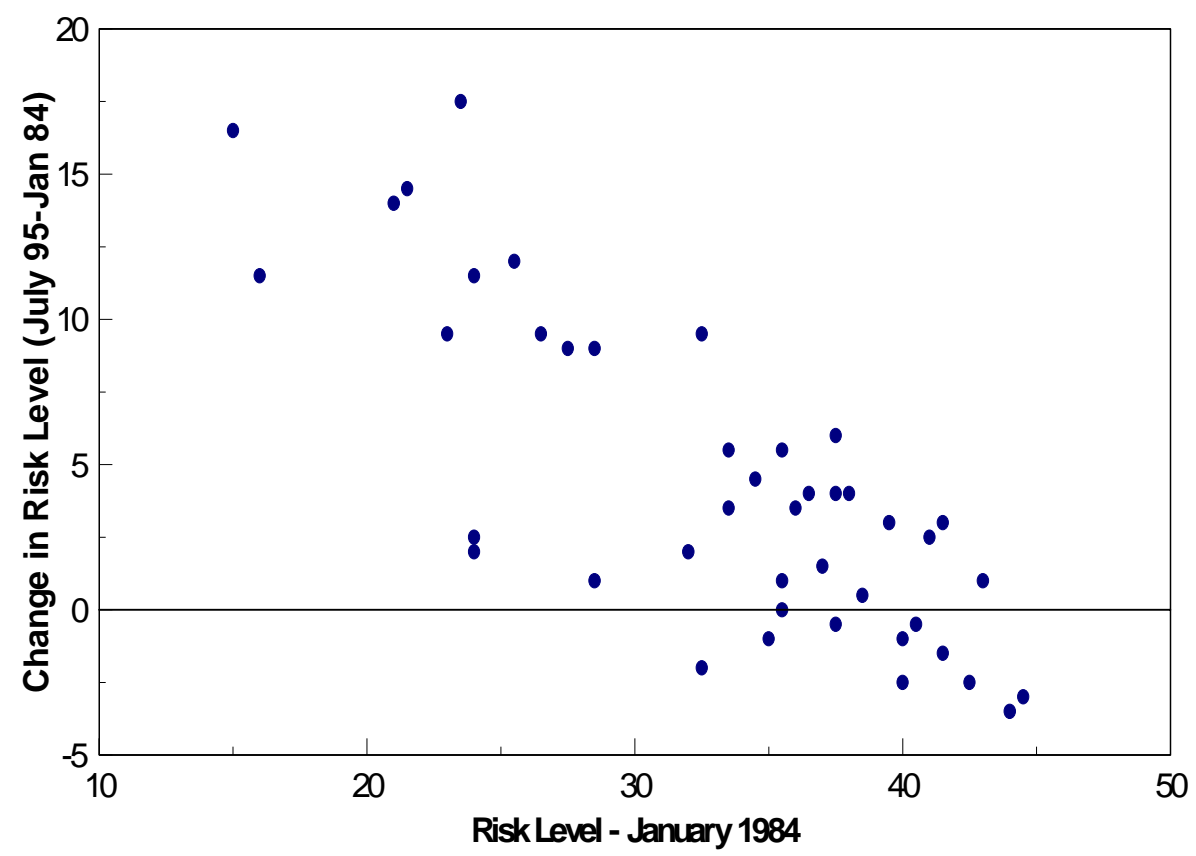

Sample: All Countries

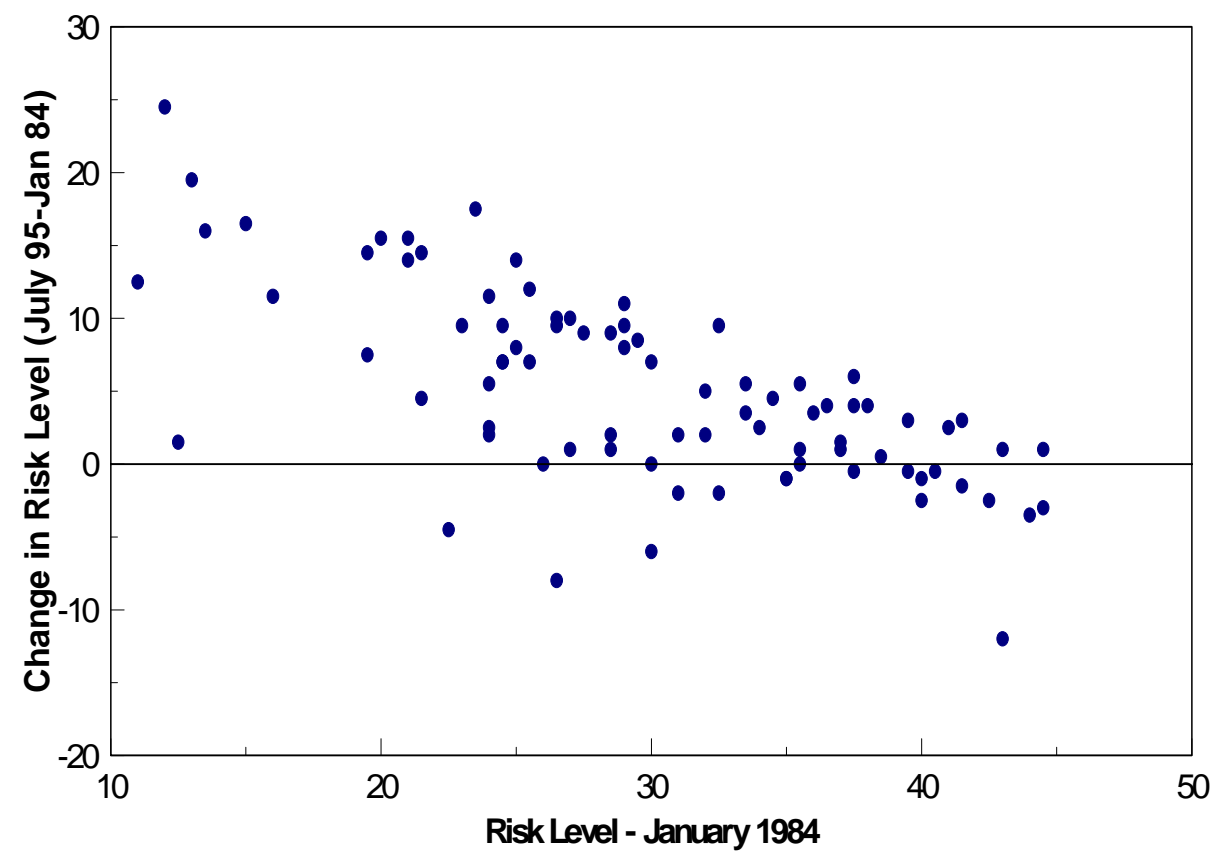


Figure 3

Equity Risk and Country Risk Ratings

\section{January 1984-July 1995}

A. Exposure to World Market

Institutional Investor Country Credit Rating

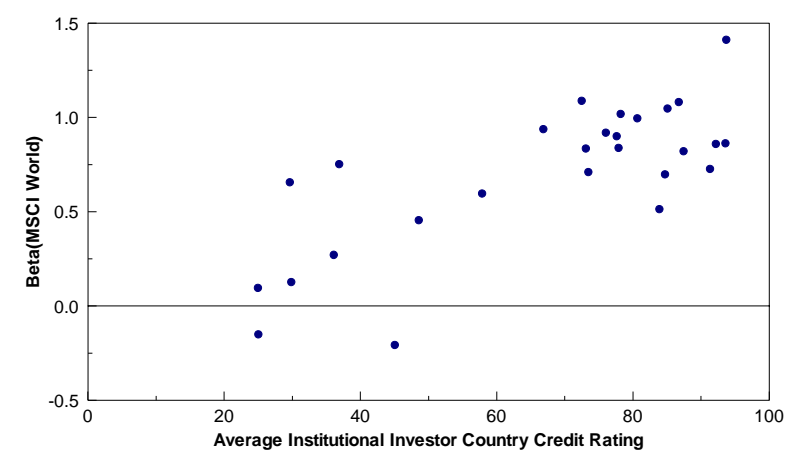

ICRG Political Rating

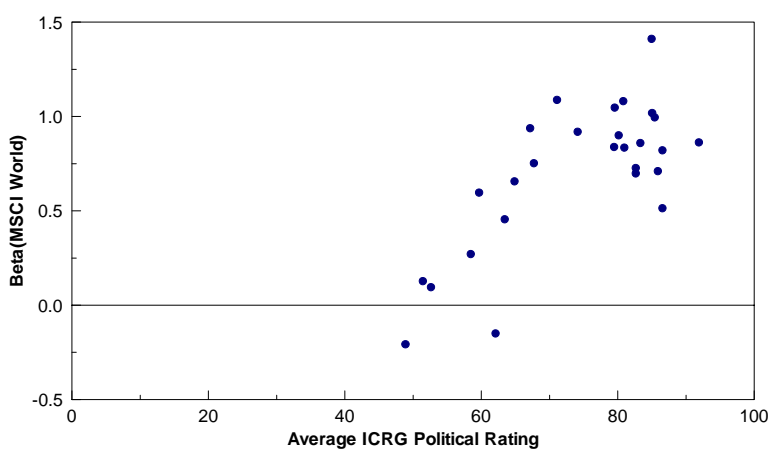

ICRG Financial Rating

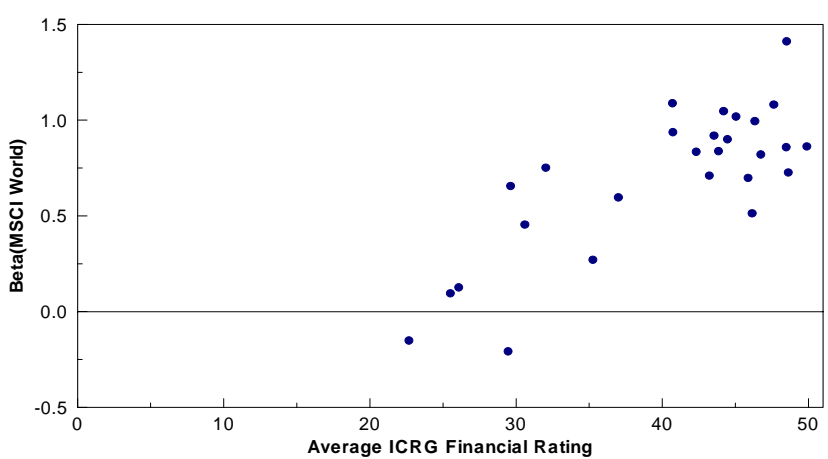

ICRG Composite Rating

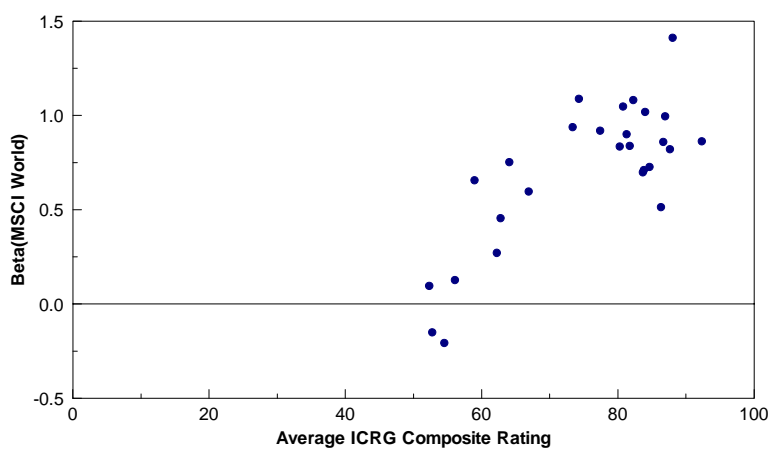

ICRG Economic Rating

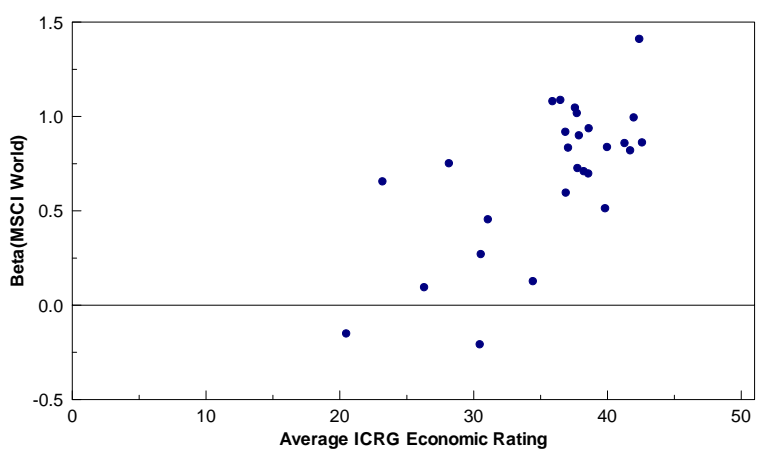


Figure 3

\section{Equity Risk and Country Risk Ratings}

January 1984-July 1995

B. Annualized Standard Deviation

Institutional Investor Country Credit Rating

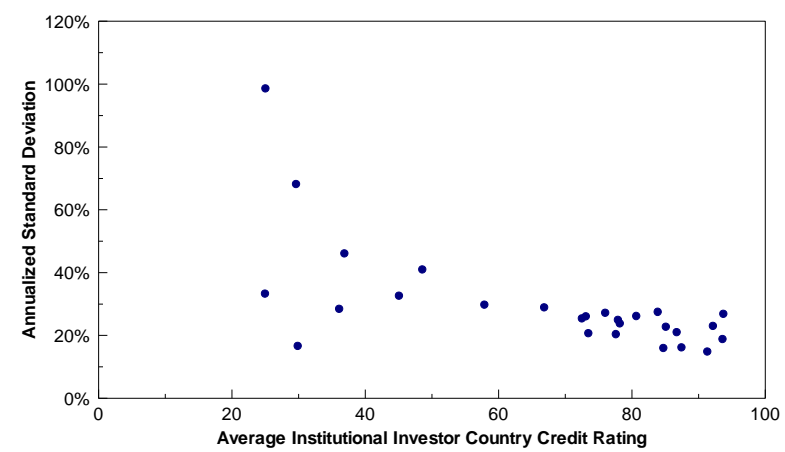

ICRG Political Rating

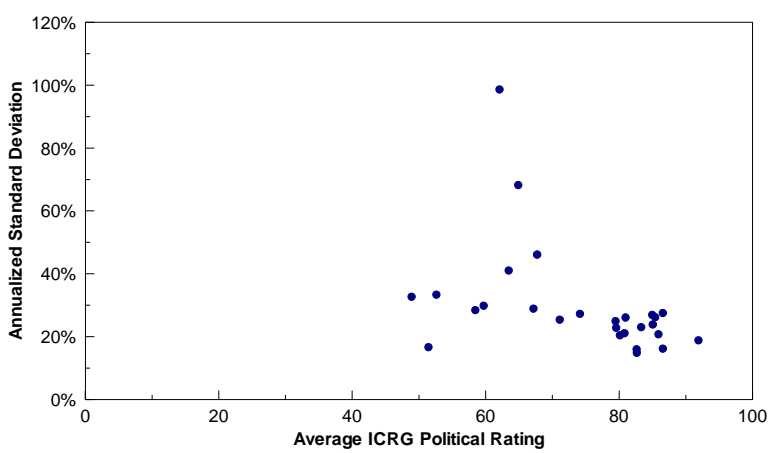

ICRG Financial Rating

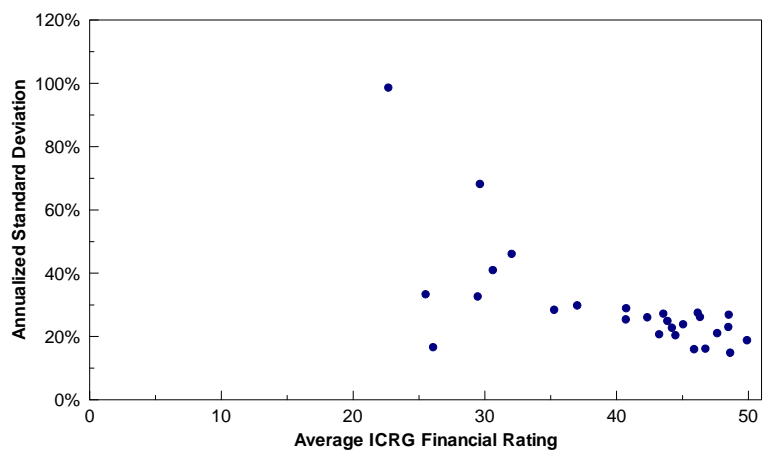

ICRG Composite Rating

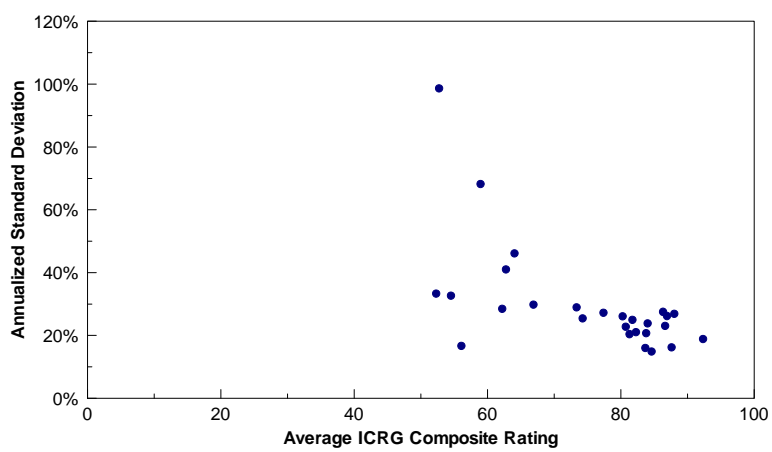

ICRG Economic Rating

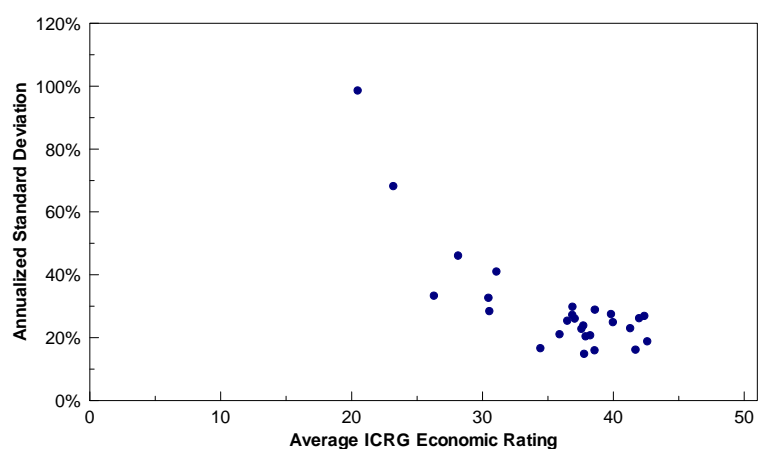

